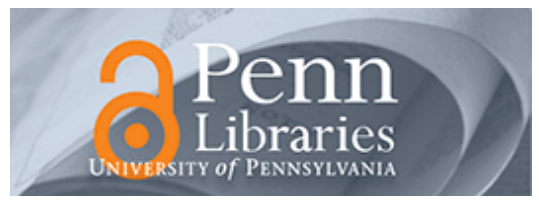

University of Pennsylvania ScholarlyCommons

\title{
$4-2011$
}

\section{Market-to-Revenue Multiples in Public and Private Capital Markets}

Christopher S. Armstrong

University of Pennsylvania

Antonio Davila

George Foster

John R. M. Hand

Follow this and additional works at: https://repository.upenn.edu/accounting_papers

Part of the Accounting Commons, Business Administration, Management, and Operations Commons, and the Finance and Financial Management Commons

\section{Recommended Citation}

Armstrong, C. S., Davila, A., Foster, G., \& Hand, J. M. (2011). Market-to-Revenue Multiples in Public and Private Capital Markets. Australian Journal of Management, 36 (1), 15-57. http://dx.doi.org/10.1177/ 0312896211401682

This paper is posted at ScholarlyCommons. https://repository.upenn.edu/accounting_papers/90

For more information, please contact repository@pobox.upenn.edu. 


\title{
Market-to-Revenue Multiples in Public and Private Capital Markets
}

\author{
Abstract \\ The behavior and determinants of market-to-revenue ratios in public and private capital markets is \\ examined. Three samples are analysed: (1) all publicly traded stocks listed at some time on the New York \\ Stock Exchange/American Stock Exchange/National Association of Securities Dealers Automated \\ Quotation System in the 1980-2004 period; (2) sample of over 300 so-called 'internet companies' in the \\ 1996-2004 period; and (3) over 5500 privately held venture capital-backed companies in the 1992-2004 \\ period. Both company size and the most recent revenue growth rate are found to explain significant \\ variation across companies in their market-to-revenue multiples - smaller companies and companies \\ with higher recent revenue growth rates have higher multiples. We also document how the capital market \\ appears to use a broad-based information set when setting market-to-revenue multiples for companies \\ with negative revenue growth rates - transitory revenue growth components appear to be identified (in a \\ probabilistic sense) by the capital market. Contrary to much anecdotal comment, we present evidence \\ that the capital market behaved directionally along the lines predicted by capital market theory in the \\ pricing of internet stocks in the 1996-2004 period.

\section{Keywords} \\ internet companies, market-to-revenue multiple, price/sales ratio, private companies, public companies, \\ transitory revenue, venture capital \\ Disciplines \\ Accounting | Business Administration, Management, and Operations | Finance and Financial Management
}




\title{
MARKET-TO-REVENUE MULTIPLES IN PUBLIC AND PRIVATE CAPITAL MARKETS*
}

\author{
BY \\ Christopher S. Armstrong ${ }^{\mathrm{a}}$, Antonio Davila ${ }^{\mathrm{b}}$, George Foster ${ }^{\mathrm{c}}$ and John R.M. Hand ${ }^{\mathrm{d}}$ \\ ${ }^{a}$ Christopher S. Armstrong, Assistant Professor of Accounting, The Wharton School, \\ University of Pennsylvania, USA. \\ ${ }^{\mathrm{b}}$ Antonio Davila, Professor of Entrepreneurship and Accounting and Control, IESE, \\ Spain. \\ ${ }^{c}$ George Foster, Wattis Professor of Management and Dhirubhai Ambani Faculty Fellow \\ in Entrepreneurship, Graduate School of Business, Stanford University, USA. \\ d John R.M. Hand, H. Allen Andrew Distinguished Professor of Entrepreneurship, \\ Finance and Accounting, Kenan-Flagler Business School, University of North \\ Carolina, USA. \\ * Correspondence to gfoster@stanford.edu \\ Christopher Armstrong is grateful for financial support from the Dorinda and Mark \\ Winkelman Distinguished Scholar Award. George Foster thanks the support of the Center \\ for Entrepreneurial Studies at the Graduate School of Business, Stanford University. The \\ comments of Ray Ball, Bill Beaver, Philip Brown, Ron Kasznik and Charles Lee and \\ participants at workshops at Stanford University and the University of New South Wales \\ are greatly appreciated. \\ (C) Armstrong et al, 01/24/2011
}




\begin{abstract}
The behavior and determinants of market to revenue ratios in public and private capital markets is examined. Three samples are analyzed : (1) all publicly traded stocks listed at some time on the NYSE/AMEX/NASDAQ in the 1980 to 2004 period, (2) sample of over 300 so-called "internet companies" in the 1996 to 2004 period, and (3) over 5,500 privately held venture capital backed companies in the 1992 to 2004 period. Both company size and the most recent revenue growth rate are found to explain significant variation across companies in their market to revenue multiples-smaller companies have higher multiples and companies with higher recent revenue growth rates have higher multiples. We also document how the capital market appears to use a broad based information set when setting market to revenue multiples for companies with negative revenue growth rates - transitory revenue growth components appear to be identified (in a probabilistic sense) by the capital market. Contrary to much anecdotal comment, we present evidence that the capital market behaved directionally along the lines predicted by capital market theory in the pricing of internet stocks in the 1996 to 2004 period.
\end{abstract}

KEY WORDS: MARKET TO REVENUE MULTIPLE, PRICE/SALES RATIO, PUBLIC COMPANIES, PRIVATE COMPANIES, VENTURE CAPITAL, INTERNET COMPANIES, TRANSITORY REVENUE 


\section{Introduction}

The market capitalization to revenue ratio (sometimes called price/sales ratio) is of central interest in many areas of capital market investment analysis and research. These areas include fundamental analysis, acquisition analysis, and examination of returns from quantitative investment trading strategies. ${ }^{1}$ Revenue forecasts now are part of most security analyst reports. ${ }^{2}$ This paper provides an extensive analysis of market capitalization to revenue multiples (hereafter $\mathrm{MKT}_{\mathrm{t}} / \mathrm{REV}_{\mathrm{t}}$ ) and their drivers. We examine $\mathrm{MKT}_{t} / \mathrm{REV}_{\mathrm{t}}$ multiples for three samples, each of which is of much interest in its own right. Sample One includes all publicly-traded stocks listed at some time on the NYSE, AMEX or NASDAQ over the 1980 to 2004 period. Sample Two comprises roughly 300 publicly-traded "Internet companies;" the sample has most of its observations in the 1996-2004 period. Sample Three comprises over 5,500 privately-held, venture-backed companies from primarily the 1992-2004 period. Comparisons across the three samples strengthens the reliability of the inferences we draw about the behavior and determinants of $\mathrm{MKT}_{\mathrm{t}} / \mathrm{REV}_{\mathrm{t}}$ multiples.

Key findings in this paper include: (1) Company size is a significant predictor of $M K T_{t} / R V_{t}$ ratios with smaller companies having higher $\mathrm{MKT}_{t} / \mathrm{REV}_{\mathrm{t}}$ ratios; (2) Past revenue growth is a significant predictor of the level of the $\mathrm{MKT}_{\mathrm{t}} / \mathrm{REV}_{\mathrm{t}}$ ratio; and (3) the capital market takes into account transitory components of revenue when setting $\mathrm{MKT}_{\mathrm{t}} / \mathrm{REV}_{\mathrm{t}}$ ratios. Underlying factors explaining these findings are examined. The use of data pre, during, and post the 1998 to 2000 period also enables us to explore factors associated with the so-called "internet bubble" period. Our results are consistent with the capital market behaving in this period more rationally along the predictions of capital market theory than many observers are willing to recognize.

\footnotetext{
${ }^{1}$ See, for instance, O’Hara and Lowry (2009).

2 IBES started reporting security analyst revenue forecasts approximately 20 years after it started reporting EPS forecasts. It started reporting one-year ahead and two-year ahead revenue (EPS) forecasts in 1996 (1976). It started reporting long term revenue (EPS) growth forecasts in 1999 (1981). By 2004, $85.18 \% / 83.68 \%$ of companies in the IBES sample of companies had one-year ahead/two-year ahead security analyst revenue forecasts; the comparable percentages for one-year ahead/two-year ahead EPS forecasts were 90.87\%/89.50\%. Ertimur, Mayew, and Stubben [2011] probe explanations for the issuance of revenue and expense forecasts by security analysts.
} 


\section{Importance of Research and Literature Review}

The findings in this paper have relevance for multiple research areas, including capital market valuation research, management of reported financial numbers research, capital market 19982001 "bubble" research, and early-stage company research.

\section{Capital Market Valuation Research}

Much valuation research using market multiples has emphasized market (price) to earnings or market to book value. $\mathrm{MKT}_{\mathrm{t}} / \mathrm{REV}_{\mathrm{t}}$ analysis is also important in valuation research. Analysis of market-to-revenue multiples can be motivated by both the revenue variable itself being an informative signal about future value-relevant parameters and by revenues being a "substitute" variable for situations in which negative earnings or book value are encountered.

A growing number of studies have documented the differential or incremental information content of revenue vis-à-vis other variables. Ertimur, Livnat, and Martikainen [2003] report that a dollar of surprise in revenues has higher capital market information content than a dollar of surprise in expenses. Hypothesized explanations include a persistence explanation, a homogeneity explanation, and an earnings management explanation. Berger [2003] argues that the persistence explanation - "investors react more strongly to a [revenue] surprise because these are less transitory than expense surprises" (p. 213) - is the most credible explanation of the three proposed. Ghosh, Gu, and Jain [2005], using an earnings response coefficient (ERC) methodology, report that "relative to the cost reduction firms, earnings for the revenue-growth firms are more persistent... revenue-supported earnings growth is likely to be more sustainable because revenue is the key value driver and its growth often reflects the underlying product differentiation strategy" (p. 19). Keung [2010] reports incremental information content to analyst revenue forecasts when they simultaneously make changes to their earnings and revenue forecasts. The research in this paper provides systematic evidence to support the revenue persistence / momentum argument. We also document across multiple samples that companies with higher positive revenue growth in the most recent year have higher $M K T_{t} / \mathrm{REV}_{\mathrm{t}}$ multiples. 
Many valuation studies on market multiples, by their choice of variable(s) to examine, exclude sizable numbers of interesting and important observations. For example, research on market (price) to earnings multiples invariably deletes observations with non-positive earnings. This deletion can have sizable impacts on the generalizability of the results. Appendix A of this paper reports the percentages of NYSE, AMEX, and NASDAQ companies with negative net income. The following percentages relate to the "high-technology" subsample (covering the computer hardware, software, telecom, and biotech/pharmaceuticals industries) and the "all other" subsample of companies listed on these exchanges:

\begin{tabular}{|c|c|c|c|c|c|}
\hline & 1985 & 1990 & 1995 & 2000 & 2004 \\
\hline High-Tech Companies & $30.3 \%$ & $37.2 \%$ & $39.1 \%$ & $56.8 \%$ & $50.3 \%$ \\
\hline All Other Companies & $16.3 \%$ & $23.1 \%$ & $17.2 \%$ & $22.3 \%$ & $22.7 \%$ \\
\hline
\end{tabular}

Companies listed on NASDAQ (on average, smaller and younger) have a higher percentage of negative net income than companies listed on the NYSE and AMEX. Core, Guay, and Van Buskirk [2003], in a study of market to book value multiples, report losing 5,355 observations (4.7\%) from their sample when requiring companies to have positive book value. They note that "deleting firms with negative book value of equity removes a greater percentage of young $(7.5 \%)$ and high-technology (5.6\%) firms" (p. 51).

Research that compares the relative "performance" of $\mathrm{MKT}_{\mathrm{t}} / \mathrm{REV}_{\mathrm{t}}$ vis-à-vis other market multiples highlights the potentially severe deletion that can occur in traditional $\mathrm{MKT}_{t} / \mathrm{INC}_{\mathrm{t}}$ or $\mathrm{MKT}_{\mathrm{t}} / \mathrm{BV}_{\mathrm{t}}$ multiple studies. Consider the Liu, Nissim, and Thomas [2002] study which adopted a "horse-race" ranking methodology in which the ability of alternative accounting variables to predict the current stock price was compared. The variables included six historical series (cash flow, cash flow from operations, EBITDA, revenues (sales), earnings, and book value of equity) and two forward-looking series (analyst forecasts of EPS and long-term growth in EPS). The 
conclusion was that "despite the importance of top-line revenues, its value-relevance is limited until it is matched with expenses" (pp. 137-138). The sample examined had sizable reductions they excluded "firm-years with negative values for any value driver" and "firms not covered by IBES, typically firms with low and medium market capitalization." The authors noted that their "results may not be descriptive of startup firms reporting losses and high growth firms with negative operating cash flows" (p. 138).

The research in this paper examines $\mathrm{MKT}_{\mathrm{t}} / \mathrm{REV}_{\mathrm{t}}$ multiples. The observations we delete due to non-positive denominators are minimal vis-à-vis studies on $\mathrm{MKT}_{\mathrm{t}} / \mathrm{INC}_{\mathrm{t}}$ or $\mathrm{MKT}_{\mathrm{t}} / \mathrm{BV}_{\mathrm{t}}$ multiples. ${ }^{3}$ Moreover, we present results for different samples, some of which represent companies with below average representation in previous research on market multiples (namely technology and smaller companies). The privately-held venture-backed company sample we examine has only recently been the subject of empirical research. Our results highlight how companies with either negative net income or negative book value can still be the subject of capital market multiple research as opposed to being ignored in a "deleted observations" subsample.

\section{"Management" of Reported Financial Numbers}

The earnings management literature has examined multiple dimensions, including analysis of the revenue series, various expense series, balance sheet items, and cash flow items. Stubben [2010] examines the ability of revenue and accrual models to detect simulated and actual earnings management. Callen, Robb, and Segal [2004] illustrate research with a focus on the revenue series. They report finding that "revenues are value relevant in explaining market value of equity whereas earnings are not significant in explaining the market value of equity for firms reporting negative earnings. Given our assumption that revenue manipulation flows though accounts receivable, we show that firms with a more extreme string of past and anticipated losses report higher accounts receivable to sales ratio" (p. 30). Bowen, Davis, and Rajgopal [2002] study

\footnotetext{
${ }^{3}$ An analysis of Compustat companies listed on the NYSE, AMEX, or NASDAQ finds only 15 negative annual revenue observations over the 1980-2004 period. We examined the respective 10K's of each of the 15 negative revenue observations -3 were errors in Compustat.
} 
revenue reporting policies of internet companies. They report that "the pressure to seek external financing influences Internet managers' choices to report barter and/or grossed-up revenue." The transitory revenue results in Section VIII of this paper provide further insight into how the reported revenue series may differ from that which the capital market views as value relevant.

\section{Analysis of 1998-2000 Capital Market "Bubble"}

Phrases such as "bubble period," "irrational exuberance," and "Internet euphoria" have been used to describe the 1998 to 2000 capital market period. There were major swings in the market capitalization of many companies in this period. Multiple studies have been undertaken of the valuation of Internet companies in this period (see for example, Trueman, Wong, and Zhang [2000, 2001] and Hand [2001, 2003]). These studies typically analyze companies in the era when stock prices were increasing or at historically ex post high levels. Core, Guay, and Van Buskirk [2003] examine the determinants of market to book value multiples for several samples (all firms, high-tech and young firms) in the 1975 to 1999 period. They conclude that while the regression models' "explanatory power decline in the New Economy subperiod... the regression model's structure during the New Economy subperiod is not unusual compared to other subperiods" (p. 43).

We analyze the 1980 to 2004 period, which includes the subsequent dramatic reductions in market capitalization of many stocks as well as their prior sizable runups. This coverage provides a stronger foundation to make inferences about the 1998-2000 period vis-à-vis other periods. Moreover, we examine venture-backed privately-held companies as well as publicly-traded companies. This sample provides further insight into the so-called "bubble period" as many public companies with dramatic increases in market capitalizations in the 1998-2000 period came from our venture-backed sample of companies.

\section{Early-Stage Company Valuation and Growth}


There is an emerging literature on how early stage companies grow over time and the factors that affect their valuation. One stream of this literature has focused on the valuation and financial evolution of privately-held venture capital backed companies (see, for example, Davila, Foster, and Gupta [2003], Hand [2005], and Armstrong, Davila, and Foster [2006]). Another stream of research examines revenues and revenue forecasts of these companies (see, for example, Armstrong, Davila, Foster, and Hand [2007]). A third stream examines the evolution of the management control systems (including revenue/sales budgeting) of early-stage companies - see, for example, Davila [2005], Davila and Foster [2005, 2007], Sandino [2007], Davila, Foster and Li [2009], and Davila, Foster and Jia [2010]. Research is also focusing on the financial statements prepared or released by start-up or privately held ventures - see Cassar [2009] and Allee and Yohn [2009]. Hand [2011] documents how, for a sample of 1,133 venture-backed companies, both financial (current year revenues) and non-financial (patents, headcount, etc.) explain oneyear-ahead revenue forecasts. Extensive evidence on the revenue growth rates of early-stage companies in many countries is in Foster, Davila, Haemmig, He, Jia, von Bismarck and Wellman [2011]. The research in this paper extends this literature by examining factors that explain differences in the revenues of early-stage companies as well as the drivers of early-stage company valuation.

\section{RESEARCH HYPOTHESES EXAMINED}

We examine the following three hypotheses:

- Hypothesis One. Smaller companies have higher $\mathrm{MKT}_{\mathrm{t}} / \mathrm{REV}_{\mathrm{t}}$ ratios. Smaller companies are hypothesized to have greater potential for future higher revenue growth rates. There is strong evidence supporting Hypothesis One. This finding highlights the impact that sample deletion procedures can play in excluding interesting and important observations. Smaller companies, on average, are more likely to have negative net income or negative book value. They are also less likely to have extensive analyst coverage. In our samples, smaller companies are more likely to come from the high technology sector where intangible assets are of much interest. Revenues for 
such companies potentially are an important signal that they are converting "investments" in intangible assets (ideas, innovations, discoveries, development of a sales force, etc.) into products/services commercially valued by customers or partners.

- Hypothesis Two. Companies with higher recent positive revenue growth rates will have higher $\mathrm{MKT}_{t} / \mathrm{REV}_{\mathrm{t}}$ ratios than companies with lower recent positive revenue growth rates. Past revenue growth is hypothesized to have significant momentum (i.e., persistence) such that the higher the most recent year's revenue growth, the higher the likely future revenue growth. There is strong evidence supporting Hypothesis Two.

- Hypothesis Three. Companies with negative reported revenue growth and higher $\mathrm{MKT}_{\mathrm{t}} / \mathrm{REV}_{\mathrm{t}}$ ratios have a higher likelihood of negative transitory revenue. Transitory revenue is the difference between reported revenue and underlying revenue. The capital market is hypothesized to use a broad information set (certainly larger than just the most recent revenue growth observation) and is able to identify the companies whose current reported revenue contains a higher negative transitory component. There is strong evidence supporting Hypothesis Three.

\section{Samples of Companies Examined}

Three samples of companies are examined in this paper. These three samples were chosen to ensure sizable cross-sectional and time-series differences in $\mathrm{MKT}_{\mathrm{t}} / \mathrm{REV}_{\mathrm{t}}$ multiples of the companies examined. They were also chosen to gain insight into the 1998-2000 period where $\mathrm{MKT}_{t} / \mathrm{REV}_{\mathrm{t}}$ multiples for large numbers of publicly and privately traded companies reached levels not previously encountered.

\section{IV.A. Sample One: Publicly Traded Companies in Selected SIC Industries on NASDAQ and NYSE/AMEX}


Companies of particular interest in our research are those with extreme movements in market capitalization. Extreme variation in the numerator of the revenue multiple enables the research to probe the magnitude of any associated variation in the denominator of the market-to-revenue multiple. The 1998-2001 period is a recent period with very large variations in market capitalizations. Focusing on this period, we used the following criteria to identify two subgroups with differing variations in market capitalization.

First, we calculated the sequence of end-of-month aggregate market capitalizations from January, 1998 to December, 2001 of all companies on the NASDAQ, AMEX, and NYSE exchanges in every three-digit SIC code. For each three-digit SIC industry, we then found the:

(1) High value of that three-digit SIC industry group's market capitalization,

(2) Low value before the date of the high value but after January, 1998, and

(3) Low value after the date of the high value but before December, 2001.

Second, we then calculated the ratio of high-to-low market capitalizations (a) before the peak (from (1) and (2)), and (b) after the peak (from (2) and (3)). The average of the two ratios from (a) and (b) measures the relative increase and decrease in aggregate value of the three-digit SIC industry group during the 1998-2001 period. We next ranked all SIC industries using the average ratio and chose the top six industries with a peak individual aggregate market capitalization of at least $\$ 1$ trillion. These six SIC industries we put into four industry groups - computer hardware (SIC codes 357, 366 and 367), computer software (737), telecommunications (481), and biotechnology/pharmaceutical (283). ${ }^{4}$

\footnotetext{
${ }^{4}$ The analysis used to identify the two Sample One sub-samples is conducted at the three-digit SIC industry level and not the company level. Our industry market capitalization amounts are based on all companies listed at the chosen date of interest. As new companies list or existing companies delist, there will be a changing number of companies underlying the aggregate industry market capitalizations at different dates.
} 
Table 1 (Panel A) reports the aggregate market capitalization information (as of 1/1/1998, $3 / 10 / 2000$, and 12/31/2001) and the number of companies (as of 3/10/2000) for the following groups: ${ }^{5}$

I. All Companies

II. Pooled Selected SIC Industries (II.A + II.B + II.C + II.D)

II.A. Computer Hardware $(357,366,367)$

II.B. Computer Software (737)

II.C. Telecommunications (481)

II.D. Biotechnology/Pharmaceuticals (283)

III. All Other Companies (in I. but not in II).

At the March 10, 2000 peak, our four selected industry groups comprised approximately $50 \%$ of the total market capitalization of the NYSE/AMEX/ NASDAQ. NASDAQ firms in Group II made up 57.6\% of the total NASDAQ market capitalization. NYSE/AMEX firms in Group II made up $42.4 \%$ of NYSE/AMEX total market capitalization.

Although the Sample One selection criteria focused only on the 1998-2001 period, it is interesting to note that our Selected SIC industries subsample has differed from the All Other Companies subsample on several key risk related variables for many years prior to the 1998-2001 period. Appendix A reports that from at least 1985, companies in the Selected SIC Industries subsample have had (a) higher security market risk (measured by both the Beta and standard deviation of security returns), and (b) a higher percentage of companies with negative net income vis-à-vis the All Other Companies subsample. Some key differences we find between subsamples II and III in the 1998-2001 period are by construction of the research design. However, differences we observe both pre-1998 and post-2001 are not by construction.

\footnotetext{
${ }^{5}$ March 10, 2000 is the date when the NASDAQ reached its peak value (up through December 31, 2004).
} 


\section{IV.B. Sample Two: Publicly Traded Internet Companies}

In the late 1990's and early 2000's the phrase "internet company" was used to describe many

new companies where the internet played a key role in user engagement or revenue yield.

Revenues rather than net income was the more frequently used financial statement item in valuation analysis of these so-called Internet companies. This was in part due to most such companies not having positive net income, especially in the 1998-2001 period. Sample Two comprises publicly traded Internet companies drawn from a database on Jay Ritter's website (used in Loughran and Ritter [2004]). The database is built from a merging of "Internet identifications of Thompson Financial Securities Data, Dealogic, and IPOMonitor.com” (p.1). ${ }^{6}$

To facilitate comparisons with our SIC industry analysis, we cross-classified the Internet sample with our SIC based groupings. The overlap is strongest for computer software, computer hardware, and telecommunications industries. However, one other three digit SIC industry (738 Miscellaneous Business Services) accounted for over $10 \%$ of the Internet sample (as of $3 / 10 / 2001)$.

Table 1 (Panel B) lists the aggregate market capitalizations (as of 1/1/1998, 3/10/2000, and 12/31/2001) and the number of companies (as of March 10, 2000) for the following groups:

I. All Internet Companies

II. Pooled Selected Internet-SIC Industries (II.A + II.B + II.C + II.D)

II.A. Internet-Computer Hardware

\footnotetext{
${ }^{6}$ There is no universally agreed upon definition of an Internet company. The accounting literature has relied heavily on the InternetStockList ${ }^{\mathrm{TM}}$ (ISL) reported on www.internet.com. The ISL was billed by www.internet.com as a complete list of all publicly traded Internet stocks. An Internet stock was operationally defined as a stock that existed because of the Internet - that is, had there been no Internet, the stock would not be in existence. Papers that use the ISL include Trueman, Wong and Zhang (2000, 2001), Demers and Lev (2001), Hand (2001), Bartov, Mohanram and Seethamraju (2002), Davis (2002), Demers and Lewellen (2003), Keating, Lys and Magee (2003), and Bauman, Bauman and Das [2010]. Depending on whether the authors were targeting all Internet firms or just a subset (e.g., only B2C firms), sample sizes these papers analyzed range between 24 and 261. The finance literature approach appears to be to identify which new IPOs have an internet connection. The Ritter database has this approach as does Schultz and Zaman [2001], Ljungqvist and Wilhem [2003], and Ofek and Richardson [2002, 2003]. The samples in these papers ranged from 393 to 538 .
} 


\section{II.B. Internet-Computer Software \\ II.C. Internet-Telecommunications \\ II.D. Internet-(Miscellaneous) Business Services}

III. All Other Internet Companies (in I. but not in II.)

The "All Other Internet Companies" group (III) consists of Internet companies from many SIC industry groupings. However, no SIC industry group in (III) has more than $4 \%$ of the All Internet Company group (I).

The Internet sample is dominated by companies that went public after $1995 .{ }^{7}$ In contrast, Sample One includes companies of many different IPO and age vintages. The Internet sample is almost exclusively traded on NASDAQ. On March 10, 2000, 96.2\% of the total companies in Sample Two were listed on NASDAQ. The NASDAQ internet companies made up $97.8 \%$ of the total NASDAQ/NYSE/AMEX Internet market capitalization on that date.

\section{IV.C. Sample Three: Privately-Held Venture-Backed Companies}

Revenues are a pivotal variable for valuing privately-held venture-backed companies. Venture capital exists, in part, to finance early-stage companies whose rapid growth aspirations often result in their having negative operating cash flow (and often negative income) in their early years. Our Sample Three draws on a VentureOne database. VentureOne is a commercial organization that collects and sells information about venture-backed companies and their investors. The focus is on each company up to the time of an IPO, a trade sale or some other exit. For each company included in its database, information on private financing rounds (such as dates of funding rounds, amounts raised, and pre-money valuations) as well as details about the company's management and investors is available. Several financial statement-based numbers (revenue and net income) are also included for a subset of these companies. The database is at its

\footnotetext{
${ }^{7}$ The Internet list includes $4.1 \%$ that went IPO prior to 1996. One notable company included in the list is Cisco Systems (IPO in 1990).
} 
most comprehensive from the early 1990's onwards. Data are provided to VentureOne by companies and their investors on a voluntary basis. Where possible, VentureOne uses additional sources to verify the reported numbers (such as obtaining pre-money valuation numbers from the company itself, from individual investors, tracking business press reports on the company's financing, and publicly available regulatory reports such as S-1 filings with the SEC).

VentureOne provides its own industry classifications (16 in total) for the companies in its database. The top eight industry classifications cover $86.5 \%$ of the 13,765 companies in the database. We use these eight industries as our Sample Three, grouping them into five broader industries:

I. All Companies in Sample Three
I.A Software
I.B Consumer-Business Services
I.C Communications
I.D Biopharmaceuticals
I.E Hardware/Equipment

Table 1 (Panel C) summarizes the composition of these VentureOne industry groups. Of the 11,910 companies in Table 1 (Panel C), 1,262 had gone IPO by March 2005. We also report the number of these IPO companies that were classified as Internet companies using the Sample Two Internet company listing (from Jay Ritter's website). Approximately 18.9\% (or 239 companies) of this 1,262 IPO Sample became publicly-listed Internet companies, with most (92.8\%) of these having their IPO between 1996 and 2000. At the time of their public listing, the majority (55.25\%) of the Venture One companies with IPO's are classified into the six 3-digit SIC code industries that comprise our Selected SIC Industry group in Sample One. 


\section{Time-Series and Cross-Sectional Distribution of MKT/REV Multiples}

Figure 1 presents time-series plots from 1980-2004 for the $\mathrm{MKT}_{\mathrm{t}} / \mathrm{REV}_{\mathrm{t}}$ (the ratio of market capitalization of common equity to the most recent annual revenue) multiple for Samples One to Three. Each plot has the $90^{\text {th }}, 70^{\text {th }}, 50^{\text {th }}, 30^{\text {th }}$, and $10^{\text {th }}$ percentiles of the annual cross-sectional distribution. These percentiles are computed on a year-by-year basis. Sample One has two subsamples. Both have similar scales $(0-100)$ in Figure 1 to facilitate comparability. The Selected SIC Industries subsample was selected based on high market capitalization variation in the 1998-2001 period vis-à-vis the All Other Companies subsample. There are dramatic $\mathrm{MKT}_{\mathrm{t}} / \mathrm{REV}_{\mathrm{t}}$ multiple differences across these two subsamples in Figure 1 . The $90^{\text {th }}$ and $70^{\text {th }}$ percentiles of the Selected SIC Industries subsample are consistently higher than that of the comparable deciles for the All Other Companies subsample. The $\mathrm{MKT}_{\mathrm{t}} / \mathrm{REV}_{\mathrm{t}}$ plots for Samples Two and Three are scaled ( 0 to 350 ) higher than for Sample One to reflect the sizably higher $90^{\text {th }}$ $\mathrm{MKT}_{\mathrm{t}} / \mathrm{REV}_{\mathrm{t}}$ percentile values, especially in the 1999 to 2000 period. Specific values for the $90^{\text {th }}$ percentile across the different samples for selected years are:

\begin{tabular}{|l|c|c|c|c|c|c|c|c|}
\hline & $\mathbf{1 9 8 5}$ & $\mathbf{1 9 9 5}$ & $\mathbf{1 9 9 8}$ & $\mathbf{1 9 9 9}$ & $\mathbf{2 0 0 0}$ & $\mathbf{2 0 0 1}$ & $\mathbf{2 0 0 2}$ & $\mathbf{2 0 0 4}$ \\
\hline Sample One: NASDAQ/NYSE/AMEX & & & & & & & & \\
\hline Selected SIC Industries & 6.6 & 20.2 & 18.6 & 80.3 & 46.1 & 27.4 & 13.9 & 41.7 \\
\hline All Other Companies & 5.1 & 5.1 & 4.6 & 5.9 & 6.1 & 5.4 & 4.4 & 7.2 \\
\hline Sample Two: Internet Companies & - & - & 85.6 & 233.1 & 33.5 & 9.1 & 5.5 & 11.6 \\
\hline $\begin{array}{l}\text { Sample Three: Venture-Backed } \\
\text { Companies }\end{array}$ & - & 78.3 & 142.5 & 161.0 & 332.5 & 149.8 & 233.4 & 100.0 \\
\hline
\end{tabular}

In subsequent sections of this paper, we examine hypotheses that pertain to these time-series or cross-sectional differences in $\mathrm{MKT}_{\mathrm{t}} / \mathrm{REV}_{\mathrm{t}}$ multiples. ${ }^{8}$

\footnotetext{
${ }^{8}$ One caveat on the sizably higher levels of the Sample Three MKT $/ \mathrm{REV}_{\mathrm{t}}$ multiples is that VentureOne uses as one of its information sources the S-1 filings of companies attempting to have an IPO. This may bias the private company sample to the more successful venture-backed private companies. However, many non-IPO exits for such private companies are in trade-sales (acquisitions) for which market competition can be intense. See Appendix A of Armstrong, Davila and Foster [2006] for discussion and evidence of
} 


\section{Hypothesis One: Company Size and MKT/REV Ratios}

Hypothesis One is that smaller companies have higher MKT/REV ratios. Theoretical valuation models often include a growth term. For example, in the classic Miller-Modigliani [1961] framework, growth was defined as investments with returns greater than their cost of capital - see Fama and Miller [1972]. Much subsequent valuation research has used the Black-Scholes [1973] option-theoretic framework to incorporate growth options into equity valuation. Hypothesis One rests on smaller companies providing higher growth potential than larger companies. At an extreme level, high compound growth rates over extended periods will constrain larger companies before smaller companies due to theoretical limits imposed by the size of the market, industry or economy in which the company operates. For any innovative product that creates a given new market demand, the relative effect on a company's revenue or net income will be greater for a smaller company than for a larger company. Smaller companies may also encounter fewer regulatory obstacles in their early growth strategies.

Figure 2 shows the $90^{\text {th }}, 70^{\text {th }}, 50^{\text {th }}, 30^{\text {th }}$, and $10^{\text {th }}$ percentiles of distribution for the MKT/REV ratio for five company size categories. These five categories (in $\$$ millions of revenues) and the percentage of observations in each category for the three samples we examine are:

\begin{tabular}{|l|c|c|c|c|c|}
\hline & $\begin{array}{c}\text { I } \\
\mathbf{\$ 0 - \$ 5}\end{array}$ & $\begin{array}{c}\text { II } \\
\mathbf{\$ 5 - \$ 2 5}\end{array}$ & $\begin{array}{c}\text { III } \\
\mathbf{\$ 2 5}-\mathbf{\$ 1 0 0}\end{array}$ & $\begin{array}{c}\text { IV } \\
\mathbf{\$ 1 0 0 -} \mathbf{1 0 0 0}\end{array}$ & $\begin{array}{c}\mathbf{V} \\
\mathbf{\$ 1 0 0 0}\end{array}$ \\
\hline Sample One: NASDAQ/NYSE/AMEX & & & & & \\
\hline Selected SIC Industries & $17.5 \%$ & $23.7 \%$ & $24.8 \%$ & $23.8 \%$ & $10.2 \%$ \\
\hline All Other Companies & $10.8 \%$ & $16.4 \%$ & $21.6 \%$ & $34.1 \%$ & $17.4 \%$ \\
\hline Sample Two: Internet Companies & $10.5 \%$ & $27.3 \%$ & $31.7 \%$ & $26.2 \%$ & $4.3 \%$ \\
\hline SampleThree:Venture-Backed Companies & $32.8 \%$ & $40.1 \%$ & $21.1 \%$ & $5.9 \%$ & $0.1 \%$ \\
\hline
\end{tabular}

possible biases from a sample that is exclusively comprised of venture-backed private companies that filed for an IPO. 
Not surprisingly, Sample Three (VC-backed private companies) contains the highest percentage of observations in each of the two smallest company size categories ( $\$ 0$ - $\$ 5$ million and $\$ 5$ - $\$ 25$ million in revenue) and the lowest percentage in the largest company size category ( $>\$ 1,000$ million in revenue). The All Other Companies subsample of Sample One has the lowest percentage of observations in the two smallest categories and the highest percentage in the largest category. The Selected SIC Industries subsample has $41.2 \%$ of observations in the $\$ 0$ - $\$ 25$ million revenue size range compared to $27.2 \%$ of observations for the All Other Companies subsample of Sample One.

Figure 2 (Panel A) shows the Sample One $\mathrm{MKT}_{\mathrm{t}} / \mathrm{REV}_{\mathrm{t}}$ distribution over the 1980 to 2004 period for the five company size categories. The vertical $\mathrm{MKT}_{\mathrm{t}} / \mathrm{REV}_{\mathrm{t}}$ scalings on the five size categories are as follows: $\$ 0-\$ 5$ million (scale of 0-400); \$5-\$25 million (0-35); \$25-\$100 million (0-20); $\$ 100-\$ 1000$ million $(0-20) ;>\$ 1000$ million $(0-15)$. The $90^{\text {th }}$ percentile $\mathrm{MKT}_{\mathrm{t}} / \mathrm{REV}_{\mathrm{t}}$ value for the smallest company group ( $\$ 0-\$ 5$ million) is consistently, over time, higher than the $90^{\text {th }}$ percentile $\mathrm{MKT}_{\mathrm{t}} / \mathrm{REV}_{\mathrm{t}}$ value of the other four company size categories for both the Selected SIC Industries subsample and the All Other Companies subsample. Figure 2 (Panel B) shows company size breakdowns for Samples Two and Three. Results are shown only for a subset of years and a subset of company size categories due to either zero or minimal observations in some years or company size categories. For example, it is only since (approximately) 1996 that a sizable number of Internet companies have been publicly listed. Very few VC-backed companies with over $\$ 100$ million of revenues have remained private stand-alone companies. The vertical $\mathrm{MKT}_{\mathrm{t}} / \mathrm{REV}_{\mathrm{t}}$ scalings in Panel B on the five size categories are $\$ 0-\$ 5$ million (scale of $0-2,500$ ); \$5-\$25 million (0-300); \$25-\$100 million (0-120); \$100-\$1000 million (0-70); > \$1000 (0-25). The most extreme $\mathrm{MKT}_{t} / \mathrm{REV}_{\mathrm{t}}$ values plotted in Figure 2 (Panel B) are those for the smallest company size category for both Samples Two and Three.

In Section IX of this paper we include company size (revenues) as an independent variable in a multivariate regression analysis with $\mathrm{MKT}_{\mathrm{t}} / \mathrm{REV}_{\mathrm{t}}$ as the dependent variable. The company size 
variable consistently has a negative coefficient that is highly statistically significant across all samples examined. In the next section of this paper we explore the recent revenue growth hypothesis and highlight how company size also is central to understanding the relative effect of recent revenue growth on MKT/REV ratios.

\section{Hypothesis Two: Recent Revenue Growth and MKT/REV Ratios}

Hypothesis Two is that companies with higher recent positive revenue growth rates will have higher $\mathrm{MKT}_{\mathrm{t}} / \mathrm{REV}_{\mathrm{t}}$ ratios than companies with lower recent positive revenue growth rates. Its rationale is that the most recent revenue growth is a value-relevant predictor of future revenue growth or other value-relevant variables. The early literature on the time-series properties of accounting numbers focused on earnings. The key conclusion from multiple studies was that the first differenced earnings series was either serially uncorrelated or in some studies exhibited statistically significant negative serial correlation - see, for example, Ball and Watts [1972]. ${ }^{9}$ In contrast, the revenue series shows statistically significant evidence of positive serial correlation. We computed autocorrelations for lags 1 to 4 for the first differenced annual revenue series for companies in our two groups for Sample One. ${ }^{10}$ The time-period is 1980 to 2004 . Table 2 shows the results. For comparison purposes, we also report results for the operating income series and the income before extraordinary items series. The Selected SIC Industries group in Sample One has over 20,000 observations while the All Other Industries group has over 90,000 observations. Table 2 highlights the statistically significant evidence of positive autocorrelation for the first differenced annual revenue series for both Sample One groups. Moreover, the Selected SIC Industries group $\left(\mathrm{r}_{1}=0.36 ; \mathrm{r}_{2}=0.18 ; \mathrm{r}_{3}=0.16 ; \mathrm{r}_{4}=0.17\right)$ shows stronger positive autocorrelations than the All Other Companies group $\left(r_{1}=0.18 ; r_{2}=0.02 ; r_{3}=0.07 ; r_{4}=0.09\right)$. The positive autocorrelations for revenues in Table 2 contrasts sharply with the minimal to negative autocorrelations for both the operating income series and the income before extraordinary items series.

\footnotetext{
${ }^{9}$ Ball and Foster [1982] and Foster [1986, pp. 238-245], provide reviews of this early literature.

${ }^{10}$ Samples Two and Three have too limited a time-series for individual companies to compute comparable autocorrelations.
} 
We now explore further evidence pertaining to our Hypothesis Two - companies with higher recent positive revenue growth rates will have higher $\mathrm{MKT}_{t} / \mathrm{REV}_{\mathrm{t}}$ ratios. In Section IX we present multivariate regression results that strongly support this hypothesis. This section of our paper highlights key factors that warrant recognition in quantifying the importance of past revenue growth in MKT/REV analysis. Annual revenue growth is computed as

$$
\left(\frac{\text { Revenue }_{\mathrm{t}}}{\text { Revenue }_{\mathrm{t}-1}}-1\right) \times 100 \%
$$

For a subset of observations there is information for revenue $e_{t}$, but not for revenue $\mathrm{t}_{\mathrm{t}-1}$ in our databases. For Samples One and Two, this is primarily due to newly-listed companies. Sample Three has a subset of missing observations due to the VentureOne data not always having a full sequence of annual revenue numbers. Note that where the private company in Sample Three starts in year $\mathrm{t}$, there is no year $\mathrm{t}-1$ annual revenue number by definition. The percentage of observations that fall in the positive revenue growth (or no change), negative revenue growth, and missing observations categories are:

\begin{tabular}{|l|c|c|c|c|}
\hline & $\begin{array}{c}\text { Positive } \\
\text { Revenue } \\
\text { Change }\end{array}$ & $\begin{array}{c}\text { Negative } \\
\text { Revenue } \\
\text { Change }\end{array}$ & $\begin{array}{c}\text { Missing } \\
\text { Observation }\end{array}$ & Total \\
\hline Sample One: NASDAQ/NYSE/AMEX Companies & & & & \\
\hline Selected SIC Industries & $58.2 \%$ & $28.7 \%$ & $13.1 \%$ & $100.0 \%$ \\
\hline All Other Companies & $62.6 \%$ & $27.6 \%$ & $9.8 \%$ & $100.0 \%$ \\
\hline Sample Two: Internet Companies & $48.3 \%$ & $26.1 \%$ & $25.6 \%$ & $100.0 \%$ \\
\hline Sample Three: Venture-Backed Companies & $61.9 \%$ & $7.2 \%$ & $30.9 \%$ & $100.0 \%$ \\
\hline
\end{tabular}

The "missing observation" category appears to be not a random sample and is of considerable interest in any study on market-to-revenue multiples or revenue growth.

\section{A. Annual Revenue Growth Rates, Industry/Sector, and Time Period}

Cross-sectional distributions of the annual revenue growth rate from 1980 to 2004 are presented in Figure 3 for the Selected SIC Industries (Panel A) and All Other Companies (Panel B) subsamples of Sample One. Several patterns are observable in Figure 3. First, the $90^{\text {th }}$ percentile 
for the Selected SIC Industries group consistently exceeds the $90^{\text {th }}$ percentile for the All Other Companies Group over the 1980-2004 period. The Selected SIC Industries has consistently had higher revenue growth in the upper tail of its distribution. Second, there is consistently larger revenue growth variability for the Selected SIC Industries group than the All Other Companies group. One measure of variability in revenue growth is the $90^{\text {th }}$ to $10^{\text {th }}$ interpercentile range. Panel C in Figure 3 plots this interpercentile range for the two groups over the 1980 to 2004 period. For 1999 and 2000, the interpercentile range had values of $266 \%$ and $305 \%$, respectively, which is well above the range outside of the 1998-2000 period. Every year from 1980 to 2004, the interpercentile range for the Selected SIC Industries is larger. Recall that the industries in the two subsamples were chosen using only 1998-2001 information. The results in Figure 3 and Appendix A highlight how the Selected SIC Industries exhibited higher variability and higher risk in both capital market and fundamental measures long before the 1998-2001 period. ${ }^{11}$

The $\mathrm{MKT}_{\mathrm{t}} / \mathrm{REV}_{\mathrm{t}}$ multiples in Figure 1 for Sample Two (the Internet Sector) typically exceed those for the Selected SIC Industries in Figure 1 for comparable years. Figure 4 presents annual revenue growth rates for the $90^{\text {th }}, 70^{\text {th }}$, and $10^{\text {th }}$ percentiles that highlight that Sample Two, likewise has higher revenue growth rates vis-à-vis Sample One for the $90^{\text {th }}$ and $70^{\text {th }}$ percentiles, especially in the 1998 to 2000 years. The magnitude of the $90^{\text {th }}$ and $70^{\text {th }}$ percentiles for the Internet companies (i.e., Sample Two) during 1998 to 2000 are well above either of the two Sample One subgroups for comparable years and well above historical revenue growth rates for the Sample One subgroups before the advent of Internet companies.

\footnotetext{
11 The higher risk Selected SIC Industries subsample had dramatically higher positive security returns in the 1998-2000 period. Capital market theory would predict that these companies would also have dramatically more negative security returns in the event of a market decline. This is exactly what happened by December 2001. Table 1 shows the following aggregate market capitalizations (in $\$$ billions):

\begin{tabular}{|l|c|c|c|}
\hline & $1 / 1 / 1998$ & $3 / 10 / 2000$ & $12 / 31 / 2001$ \\
\hline Selected SIC Industries & $\$ 2,849$ & $\$ 9,262$ & $\$ 4,593$ \\
\hline All Other Companies & $\$ 8,202$ & $\$ 9,135$ & $\$ 9,619$ \\
\hline
\end{tabular}
}


Figure 4 also plots annual revenue growth rate deciles for the privately-held venture-backed companies (Sample Three). The vertical scales for Samples One and Two in Figure 4 are identical ( $90^{\text {th }}$ percentile: scale of $0-800 \%$; $70^{\text {th }}$ percentile: $\left.0-300 \%\right)$ to visually highlight the higher annual revenue growth for the Internet Companies vs. the Selected SIC Industries and for the Selected SIC Industries vs. All Other Companies. Sample Three is scaled differently $\left(90^{\text {th }}\right.$ percentile: scale of $0-2,000 \% ; 70^{\text {th }}$ percentile: $0-500 \%$ ) to avoid differences across other samples being visually diminished by the extreme revenue growth rates for the venture-backed private companies. Sample Three has even higher annual revenue growth rates than either Samples One or Two. Note also the dramatic declines in annual revenue growth rates in Figure 4 for the Selected SIC Industries (in 2001), the Internet companies (in 2001), and the venture-backed companies (in 2002 and 2003).

Table 3 shows the distribution $\left(10^{\text {th }}, 20^{\text {th }}, \ldots, 80^{\text {th }}, 90^{\text {th }}\right.$ percentiles $)$ of revenue growth rates for our five different size company categories and for the pooled sample. The data in Table 3 highlights how smaller companies have both higher negative revenue growth rates (see the $10^{\text {th }}$ and $20^{\text {th }}$ percentiles) and higher positive revenue growth rates (see the $80^{\text {th }}$ and $90^{\text {th }}$ percentiles).

\section{B. MKT/REV Multiples and Sign/Size of Revenue Growth Rates}

Other things being equal, it is expected that the capital market favorably values companies with positive recent revenue growth vis-à-vis companies with negative revenue growth. Table 4 reports distribution statistics $\left(10^{\text {th }}\right.$ percentile, $50^{\text {th }}$ percentile, $90^{\text {th }}$ percentile) for the $M K T_{t} / R V_{t}$ multiple for three mutually exclusive groups:

A.) Companies with positive or zero reported revenue growth in the most recent year,

B.) Companies with negative reported revenue growth in the most recent year, and 
C.) Companies without the prior or current year's reported revenue number in the database with which to compute a revenue growth rate (typically, these are newlylisted companies in Samples One and Two ${ }^{12}$ )

These three groups do not appear to have similar $\mathrm{MKT}_{\mathrm{t}} / \mathrm{REV}_{\mathrm{t}}$ distributions, especially in their upper tails. The groups with the highest $\mathrm{MKT}_{t} / \mathrm{REV}_{\mathrm{t}}$ observations in their upper tails are typically those in either the negative revenue growth group or the missing revenue growth group. This is counter to the expectation noted above.

Consider the $\mathrm{MKT}_{t} / \mathrm{REV}_{\mathrm{t}}$ distribution comparison between the negative revenue growth group and the positive revenue growth group. The ratio of the $90^{\text {th }} \mathrm{MKT}_{\mathrm{t}} / \mathrm{REV}_{\mathrm{t}}$ percentile of the negative revenue growth group to the $90^{\text {th }} \mathrm{MKT}_{\mathrm{t}} / \mathrm{REV}_{\mathrm{t}}$ percentile of the positive revenue growth group exceeds one for most years. Summary data for this ratio are:

\begin{tabular}{|l|c|c|c|}
\hline & Time Period & $\begin{array}{c}\text { Average } \\
\text { Ratio }\end{array}$ & $\begin{array}{c}\text { \# Years with } \\
\text { Ratio }>\text { 1 }\end{array}$ \\
\hline Sample One: NASDAQ/NYSE/AMEX & & & \\
\hline Selected SIC Industries & $1980-2004$ & 2.36 & $22 / 25$ \\
\hline All Other Companies & $1980-2004$ & 1.58 & $22 / 25$ \\
\hline Sample Two: Internet Companies & $1997-2004$ & 5.26 & $3 / 8$ \\
\hline SampleThree:Venture-Backed Companies & $1992-2004$ & 31.87 & $13 / 13$ \\
\hline
\end{tabular}

For Samples One and Three, there is a consistent pattern for the $90^{\text {th }} \mathrm{MKT}_{t} / \mathrm{REV}_{\mathrm{t}}$ percentile for the negative revenue growth group exceeding that of the positive revenue growth group. The pattern for Sample Two (Internet companies) is less consistent. While the mean ratio of 5.26 is greater than 1, it is heavily impacted by the 1995 observation where the $90^{\text {th }}$ percentile is $2,101.6$. The $\mathrm{MKT}_{\mathrm{t}} / \mathrm{REV}_{\mathrm{t}}$ distribution for the missing revenue observation sample is typically even more positively skewed than the other two groups in Table 4.

\footnotetext{
${ }^{12}$ For companies in Sample Three, there is occasionally a missing current year's reported revenue number due to the absence of a regulatory mandate for private companies to publicly disclose financial data. VentureOne relies in part on voluntary disclosure by private companies in their financial data bases and also on regulatory disclosures. (S-1 filings associated with an IPO are a key data source. These S-1 filings can be used to "back-fill" numbers not previously publicly disclosed.)
} 
Hypothesis Three explores the potential role of transitory revenue in explaining the extreme positive skewness in $\mathrm{MKT}_{\mathrm{t}} / \mathrm{REV}_{\mathrm{t}}$ ratios for the negative revenue growth subsample in Table 4.

\section{Hypothesis Three: Transitory Revenue and MKT/REV Ratios}

Hypothesis Three is that companies with negative revenue growth and higher $\mathrm{MKT}_{t} / \mathrm{REV}_{\mathrm{t}}$ ratios have a higher likelihood of negative transitory revenue. The concept of transitory revenue is a potential explanation for the Table 4 counter-intuitive result that the median and upper percentiles of the MKT/REV ratio of companies with negative revenue growth exceed those with positive revenue growth.

Transitory revenue is linked to reported revenue and underlying revenue as follows:

$\begin{array}{lccc}\text { Reported } & \text { Underlying } \\ \text { Revenue } & \text { Revenue } & + & \text { Transitory } \\ & & \text { Revenue }\end{array}$

Reported revenue is what each company reports in its financial statements. We compute MKT/REV as market capitalization at the end of the fiscal year end divided by the reported revenue for that fiscal year. Underlying revenue is the (unobservable) variable that the capital market perceives as relevant to capturing the ongoing revenue generating capacity of a company in a given period. Transitory revenue are components that are noise in inferring underlying revenue from reported revenue. ${ }^{13}$ Examples of components include random and "one-off” events, activities by management to shift/misrepresent reported revenues across periods, and the revenues that result from using accounting methods not viewed as appropriate by the capital market.

\section{Revenue Growth Transition Matrix Analysis}

\footnotetext{
${ }^{13}$ Beaver and Morse [1978], Beaver [1989, pp. 91-101], and Foster [1986, pp. 436-443] provide further discussion of the "transitory" vs. "permanent" distinction with respect to reported earnings.
} 
Insight into the role of transitory revenue can be gained by examining the multi-year behavior of revenue growth from portfolios formed using $\mathrm{MKT}_{t} / \mathrm{REV}_{\mathrm{t}}$ for (a) positive revenue growth observations, (b) negative revenue growth observations, and (c) missing observations. We use several steps to construct a transition matrix:

1.) For all of the observations in year $t$, compute and rank the year $t$ revenue growth $(t / t-$ 1) for those observations with available information. Form 10 equally-sized portfolios. Portfolio 1 has the lowest (starting with the most negative) revenue growth rate and Portfolio 10 has the highest (finishing with the most positive). An $11^{\text {th }}$ portfolio of observations with missing revenue growth in year $t$ is also formed

2.) For each of the ten portfolios from step 1, compute and rank the year $t+1$ revenue growth ( $\mathrm{t}+1 / \mathrm{t})$ and form 10 equally-sized portfolios.

Table 5 presents the results in a percentage of observations format for the transition matrix. Under the null hypotheses of no association across years in revenue growth, each cell in the $10 \times 10$ matrix is expected to have the same percentage of observations. Three patterns observable in Table 5 are:

1.) The revenue "momentum" corner portfolios in Table 4 - [1,1] for successive years of lowest growth and $[10,10]$ for successive years of highest growth - have higher than expected percentages:

\begin{tabular}{|l|c|c|}
\hline & $\begin{array}{c}\text { Portfolio 1,t/ } \\
\text { Portfolio 1,t+1 }\end{array}$ & $\begin{array}{c}\text { Portfolio 10,t/ } \\
\text { Portfolio 10,t+1 }\end{array}$ \\
\hline Sample One: NASDAQ/NYSE/AMEX & & \\
\hline Selected SIC Industries & $27.42 \%$ & $37.87 \%$ \\
\hline All Other Companies & $29.60 \%$ & $34.93 \%$ \\
\hline Sample Two: Internet Companies & $26.67 \%$ & $41.82 \%$ \\
\hline SampleThree: Venture-Backed Companies & $21.15 \%$ & $36.59 \%$ \\
\hline
\end{tabular}

Momentum in the $[10,10]$ corner is consistent with economic factors giving current high revenue growth companies a sustaining advantage over multiple years (e.g., due to, say, superior 
branding, exclusive patents, deeper customer relationships, or a sustainable low-cost advantage).

Here, above average revenue growth $\mathrm{t} / \mathrm{t}-1$ is likely to indicate above average revenue growth in $t+1 / t$. Momentum in the $[1,1]$ corner is consistent with the factors giving rise to revenue decline (e.g., poor quality problems, inexperienced management repeatedly incurring self-inflicted wounds, or aggregate market declining due to a disruptive technology) persisting over multiple years.

2.) The "reversal" corner portfolios in Table 5 - $[1,10]$ and $[10,1]$ - have above expected percentages for both corners of the Sample One transition matrix, for neither of the reversal corners for the Sample Two matrix, and only the [Port 1, t; Port 10, $t+1$ ] corner for Sample Three:

\begin{tabular}{|l|c|c|}
\hline & $\begin{array}{c}\text { Portfolio 1,t/ } \\
\text { Portfolio 10,t+1 }\end{array}$ & $\begin{array}{c}\text { Portfolio 10,t/ } \\
\text { Portfolio 1,t+1 }\end{array}$ \\
\hline Sample One: NASDAQ/NYSE/AMEX & & \\
\hline Selected SIC Industries & $\mathbf{1 7 . 9 5 \%}$ & $\mathbf{1 4 . 3 7 \%}$ \\
\hline All Other Companies & $\mathbf{1 6 . 1 0 \%}$ & $\mathbf{1 3 . 9 9 \%}$ \\
\hline Sample Two: Internet Companies & $\mathbf{6 . 0 6 \%}$ & $\mathbf{5 . 4 5 \%}$ \\
\hline SampleThree: Venture-Backed Companies & $\mathbf{1 3 . 9 4 \%}$ & $\mathbf{5 . 2 3 \%}$ \\
\hline
\end{tabular}

Above average "reversal" is consistent with transitory revenue growth being a sizable component of reported revenue growth for some companies. For Samples One and Three, the [Port 1, t; Port $10, t+1]$ combination is above average. Negative transitory revenue growth in year $t$ will likely result in an annual revenue growth in year $\mathrm{t}+1$ that is above average (due to the "abnormally" low year $\mathrm{t}$ reported revenue in the numerator of year $\mathrm{t}$ and the denominator in year $\mathrm{t}+1$ ).

3.) Table 5 shows the row percentages for those observations with a missing revenue number in the $\mathrm{REV}_{\mathrm{t}} / \mathrm{REV}_{\mathrm{t}-1}$ computation. Using the portfolio cutoff points for year $\mathrm{t}+1$ we classify those observations into one of the ten $\mathrm{REV}_{\mathrm{t}+1} / \mathrm{REV}_{\mathrm{t}}$ portfolios. ${ }^{14}$ The percentage membership of the ten

\footnotetext{
${ }^{14}$ Specifically, for each Sample of companies, we form ten equally sized portfolios based on the observation's revenue growth from year $\mathrm{t}$ to year $\mathrm{t}+1$ (excluding the missing revenue growth observations). We then use the lowest and highest revenue growth for each portfolio to establish the revenue growth range
} 
revenue growth portfolios in year $\mathrm{t}+1$ indicate that the year $\mathrm{t}$ subsample with missing

observations has a disproportionately higher percentage in the higher revenue growth portfolios in year $t+1$. For example, the combined percentages in portfolios 9 and 10 are: Sample One Selected SIC Industries (52.99\%); Sample One - All Other Companies (45.32\%); Sample Two Internet Companies (56.09\%); and Sample Three - Venture-backed Companies (43.81\%). One explanation for Sample One and Two is that the newly-listed IPO companies include those from Sample Three. Figure 4 documents the quantumly higher revenue growth rates in the private company sample.

\section{Multi-Year Analysis of MKT/REV Portfolios With Different Sign of Annual Revenue}

\section{Growth}

Across each of the three samples, there is a positive revenue growth expectation. For instance, the median annual revenue growth rates are: Sample One - Selected SIC Industries (11.4\%); Sample One - All Other Companies (8.4\%); Sample Two - Internet Companies (47.1\%); and Sample Three - Venture-backed Companies (56.0\%). Hypothesis Three is that companies with reported negative revenue growth will likely include a subset where the current reported revenue number includes a sizable negative transitory component. We now examine whether the capital market sets MKTt/REVt multiples recognizing this negative transitory component in an empirically observable way. We first examine the sample with positive revenue growth observations, in part to use it as a benchmark to interpret the sample with negative revenue growth observations.

Figure 5 (Panel A) shows the median company revenue growth rates for ten portfolios ranked on the basis of their $\mathrm{MKT}_{\mathrm{t}} / \mathrm{REV}_{\mathrm{t}}$ values; Panel $\mathrm{A}$ is based only on observations with positive revenue growth in year $t$. These ten portfolios comprise the top $10 \%$, next $10 \%, \ldots$, bottom $10 \%$ of $\mathrm{MKT}_{\mathrm{t}} / \mathrm{REV}_{\mathrm{t}}$ observations for each company/year combination. By construction, they range from

of each of the ten portfolios. The observations with missing revenue growth from year $\mathrm{t}-1$ to year $\mathrm{t}$ are then assigned to one of the ten portfolios based on their revenue growth from year $t$ to year $t+1$. We report these assignments in Table 5 . 
the highest to the lowest $\mathrm{MKT}_{\mathrm{t}} / \mathrm{REV}_{\mathrm{t}}$ observations. However, this does not mechanically rank the portfolios on the basis of revenue growth. Table 6 reports the correlation between the median $\mathrm{MKT}_{t} / \mathrm{REV}_{\mathrm{t}}$ multiple of each portfolio and its median annual revenue growth. The analysis is conducted for the annual revenue growth at year $t$, year $t+1$, and year $t+2$ for the ten portfolios constructed in year t. For the subsample of observations with positive revenue growth in the year the $\mathrm{MKT}_{\mathrm{t}} / \mathrm{REV}_{\mathrm{t}}$ multiple is computed (i.e., year $\mathrm{t}$ ), there is a significant positive correlation at the portfolio level between $\mathrm{MKT}_{t} / \mathrm{REV}_{\mathrm{t}}$ and annual revenue growth in each of years 1,2 , and 3 for Samples One (both Selected SIC Industries and All Other Companies) and for Sample Three. The Internet sample has significant positive correlations in years 1 and 2 , but not in year 3 . A word of caution is appropriate in interpreting the Internet sample results. The analysis in Figure 5 is conducted in event time (rather than calendar time). The sample with the least diversification in constructing multiple sequences of calendar time to package in event time is the Internet sample. The Internet sample is heavily concentrated in the 1997 to 2002 period and exhibits the most precipitous drop in annual revenue growth in 2000 and beyond (see Figure 4). In contrast, Samples One and Three have longer time sequences to effect the time period diversification.

The general finding from Figure 5 (Panel A) is that the capital market sets higher $M K T_{t} / R_{E V}$ multiples for companies with positive revenue growth not only in year $\mathrm{t}$, but also with the realized growth rates in years $t+1$ and $t+2$. For the observations with positive annual revenue growth, there is support for both the sign and magnitude of past revenue growth as well as subsequent realized revenue growth being positively associated with $\mathrm{MKT}_{t} / \mathrm{REV}_{\mathrm{t}}$ multiples.

Figure 5 (Panel B) and Table 5 both report results for those observations with negative revenue growth. There is a key dramatic difference from the positive revenue growth observations in Figure 5 (Panel A). In the year the ten $\mathrm{MKT}_{\mathrm{t}} / \mathrm{REV}_{\mathrm{t}}$ portfolios are formed (i.e., year $\mathrm{t}$ ), there is a high negative correlation between the median $\mathrm{MKT}_{\mathrm{t}} / \mathrm{REV}_{\mathrm{t}}$ in year $\mathrm{t}$ of each portfolio and the magnitude of the revenue growth in year t. This significant negative correlation supports the 
hypothesis that reported revenue in year $t$ includes a negative transitory revenue component that the capital market takes into account. The more negative the transitory revenue component, the lower the denominator of the $\mathrm{MKT}_{\mathrm{t}} / \mathrm{REV}_{\mathrm{t}}$ computation. Hypothesis Three can be empirically probed by observing the realized annual revenue growth rates in years $t+1$ and $t+2$ for the ten portfolios in Panel B. The revenue growth rates in years $t+1$ and $t+2$ are positively correlated with the $\mathrm{MKT}_{t} / \mathrm{REV}_{\mathrm{t}}$ multiples. This flipping of the sign and magnitude of the portfolio revenue growth rates between year $\mathrm{t}$ and year $\mathrm{t}+1$ in Panel B is most marked for Samples One and Three. Our results are consistent with Hypothesis Three - the capital market sets $\mathrm{MKT}_{\mathrm{t}} / \mathrm{REV}_{\mathrm{t}}$ multiples such that the magnitude of transitory revenue is recognized; higher $M K T_{t} / \mathrm{REV}_{\mathrm{t}}$ multiples are assigned to those negative Year $\mathrm{t}$ revenue growth companies with higher realized (and presumably expected) annual revenue growth in years $t+1$ and $t+2$.

Table 6 shows results for: (a) the correlations between median $\mathrm{MKT}_{\mathrm{t}} / \mathrm{REV}_{\mathrm{t}}$ and median annual revenue growth in years $\mathrm{t}, \mathrm{t}+1$, and $\mathrm{t}+2$ (in Panel $\mathrm{A}$ ), and (b) the correlations between median annual revenue growth of the ten $\mathrm{MKT}_{t} / \mathrm{REV}_{\mathrm{t}}$ portfolios for pairs of years $\mathrm{t}, \mathrm{t}+1$, and $\mathrm{t}+2$ (in Panel B). The correlations in Panel B highlight the revenue momentum factor for the positive revenue growth subsample. It is the strongest in samples One and Three. The Internet companies in Sample Two exhibit significant evidence of revenue momentum between years $t$ and $t+1$, but none between years $t$ and $t+2$ or between years $t+1$ and $t+2$. The results for the negative revenue growth portfolios in Panel B highlight the reversal pattern associated with the negative transitory revenue component in year t. Note also the positive correlations between the median annual revenue growth rates across portfolios between years $t+1$ and $t+2$ (with the Internet sample having the lowest positive correlation). Portfolios formed on $\mathrm{MKT}_{\mathrm{t}} / \mathrm{REV}_{\mathrm{t}}$ in year $\mathrm{t}$ for a sample with negative revenue growth have positive Pearson correlations between median annual revenue growth rates in years $t+1$ and years $t+2$ of 0.98 (Sample One - Selected SIC), 0.95 (Sample One All Other), 0.45 (Sample Two - Internet), and 0.90 (Sample Three - Venture-backed). This is 
strong support for our negative transitory revenue hypothesis for the $\mathrm{MKT}_{\mathrm{t}} / \mathrm{REV}_{\mathrm{t}}$ multiples of negative revenue growth companies in year $\mathrm{t}$.

\section{Multivariate Analysis}

This section incorporates our prior analysis into a multivariate framework. Table 7 presents rank regression results that further probe the three hypotheses for our three samples. We present results for rank regressions due to the extreme observations found in each of the three samples:

\begin{tabular}{|l|l|}
\hline Dependent Variable & $\mathrm{MKT}_{\mathrm{t}} / \mathrm{REV}_{\mathrm{t}}$ \\
\hline Independent Variables & \\
\hline Company Size & $\log \left(\mathrm{REV}_{\mathrm{t}}\right)$ \\
\hline Current Revenue Growth & {$\left[\left(\mathrm{REV}_{\mathrm{t}} / \mathrm{REV}_{\mathrm{t}-1}\right)-1\right]$} \\
\hline Future Revenue Growth & {$\left[\left(\mathrm{REV}_{\mathrm{t}+1} / \mathrm{REV}_{\mathrm{t}}\right)-1\right]$} \\
\hline Profitability & $\begin{array}{l}\text { Income/Revenue if }>0 \\
\text { Neg. Income } / \text { Revenue if } \leq 0\end{array}$ \\
\hline Leverage & $\underline{\text { Long-term debt }}$ \\
\hline $1998-2000$ Time Period & Indicator $=1$ if 1998-2000 \\
\hline
\end{tabular}

Table 7 reports results for the regression with combinations of independent variables. Regression \#1 reports results that pertain to Hypothesis One which predicts a negative relationship between $\mathrm{MKT}_{t} / \mathrm{REV}_{\mathrm{t}}$ and company size. Across each of the samples for Regression \#1, this hypothesis is strongly supported. Hypothesis Two - companies with higher positive current revenue growth will have higher $\mathrm{MKT}_{\mathrm{t}} / \mathrm{REV}_{\mathrm{t}}$ - is consistently supported by the Regression 2 results.

Regressions 3 to 5 combine variables related to company size, current revenue growth, and future revenue growth (defined as the realized revenue growth in Year $t+1 /$ Year $t$ ). The future revenue growth variable is added in Regressions $3 \mathrm{~b}, 4$ and 5 to recognize that the capital market uses a broad based information set when forecasting future revenue growth. Both the current revenue growth and the future revenue growth measures are expected to have measurement error regarding capturing the expected revenue growth implicit in $\mathrm{MKT}_{t} / \mathrm{REV}_{\mathrm{t}}$. The current revenue 
growth variable $\left(\mathrm{REV}_{\mathrm{t}} / \mathrm{REV}_{\mathrm{t}-1}\right)$ will incorporate factors affecting Year $\mathrm{t}$ but not expected to affect subsequent years. The future revenue growth variable $\left(\mathrm{REV}_{\mathrm{t}+1} / \mathrm{REV}_{\mathrm{t}-1}\right)$ will incorporate factors affecting Year $\mathrm{t}+1$ that were unanticipated at the end of Year $\mathrm{t}$. Both measures also are scalars (representing one year of revenue growth) whereas the capital market likely is impounding a vector (representing revenue growth over a sequence of future years). The regression results in Regressions 1 to 5 consistently support Hypotheses 1 and 2.

Existing textbooks emphasize the importance of profitability in capital market valuation - see, for example, Palepu and Healy [2007] and Penman [2009]. Regression \#6 reports regression results for $\mathrm{MKT}_{\mathrm{t}} / \mathrm{REV}_{\mathrm{t}}$ as the dependent variable and two related profitability independent variables:

- INC/REV (Net Income/Revenues) - if net income is positive or zero

- $\quad$ NEGINC/REV (Negative Net Income/Revenues)

We include these two separate profitability variables due to prior research documenting "anomalous" results for the loss company observations. ${ }^{15}$ Results are reported for the two publicly traded company samples; the VentureOne database has limited net income observations for the privately held Sample Three companies. For both Sample One subsamples the coefficients on the two profitability variables are positive and statistically significant - the more profitable the company, the higher the $\mathrm{MKT}_{t} / \mathrm{REV}_{\mathrm{t}}$ multiple. However, the internet companies show insignificant coefficients on the two profitability variables in Regression \#6.

Regression \#7 pools the independent variables in Regression \#1 to \#6. We also include two additional variables:

- Financial leverage (long-term debt to total assets)

- 1998-2000 time period intercept dummy variable

The rank regressions in Regression \#7 provide strong support for Hypotheses One and Two in a multivariate context.

\footnotetext{
${ }^{15}$ Collins, Pincus and Xie [1999] report results showing an "anomalous significantly negative priceearnings relation using the simple earnings capitalization model for firms that report losses" (p.29).
} 
Sample Two (internet companies) alone has several changes in the sign or significance of individual independent variables for Regression \#7 vis-à-vis Regressions \#1 to \#6. In Regression \#7, the coefficient on the future revenue growth for Sample Two is positive and significant whereas the coefficient on the current revenue growth is positive but insignificant; both growth variables are positive and significant in Regression \#4 and \#5. Regression \#7 reports significant positive coefficients on the two profitability variables for Sample Two whereas they were insignificantly negative in Regression \#6.

A comparison of the $\mathrm{R}^{2 \text { ' }} \mathrm{s}$ across selected regressions provides additional insight into the differing significance of the company size, revenue growth, and profitability variables. We successively

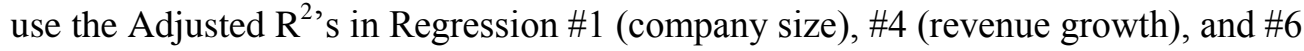
(profitability) as the numerator and the Adjusted $\mathrm{R}^{2}$ in Regression $\# 7$ as the denominator: ${ }^{16}$

\begin{tabular}{|c|c|c|c|c|c|c|c|c|}
\hline & \multicolumn{4}{|c|}{ Sample One } & \multirow{2}{*}{\multicolumn{2}{|c|}{$\begin{array}{l}\text { Sample Two } \\
\text { Internet } \\
\text { Companies }\end{array}$}} & \multirow{2}{*}{\multicolumn{2}{|c|}{$\begin{array}{c}\text { Sample Three } \\
\text { VC-Backed } \\
\text { Private Companies }\end{array}$}} \\
\hline & \multicolumn{2}{|c|}{$\begin{array}{l}\text { Selected SIC } \\
\text { Industries }\end{array}$} & \multicolumn{2}{|c|}{$\begin{array}{c}\text { All Other } \\
\text { Companies }\end{array}$} & & & & \\
\hline $\begin{array}{l}\text { Company Size } \\
(\# 1 / \# 7)\end{array}$ & $\frac{8.2 \%}{36.9 \%}$ & $=22.2 \%$ & $\frac{9.5 \%}{43.6 \%}$ & $=21.8 \%$ & $\frac{7.1 \%}{40.1 \%}$ & $=17.7 \%$ & $\frac{68.1 \%}{67.2 \%}$ & $=101.3 \%$ \\
\hline $\begin{array}{l}\text { Revenue Growth } \\
\qquad(\# 4 \text { / \#7) }\end{array}$ & $\frac{11.1 \%}{36.9 \%}$ & $=30.1 \%$ & $\frac{6.0 \%}{43.6 \%}$ & $=13.8 \%$ & $\frac{35.7 \%}{40.1 \%}$ & $=89.0 \%$ & $\frac{20.9 \%}{67.2 \%}$ & $=31.1 \%$ \\
\hline $\begin{array}{l}\text { Profitability } \\
(\# 6 / \# 7)\end{array}$ & $\frac{15.7 \%}{36.9 \%}$ & $=42.5 \%$ & $\frac{30.2 \%}{43.6 \%}$ & $=69.3 \%$ & $\frac{4.3 \%}{40.1 \%}$ & $=10.7 \%$ & & - \\
\hline
\end{tabular}

For the two Sample One subgroups of companies, profitability variables contribute the most explanatory power. Revenue growth is more important for the Selected SIC Industries than for the All Other Companies; the $\mathrm{R}^{2}$ for revenue growth variables in Regression \#4 are $30.1 \%$ of the Regression \#7 $\mathrm{R}^{2}$ for the Selected SIC Industries subsample, but only $13.8 \%$ for the All Other Companies subsample. Revenue growth is the dominant contributor for Sample Two (Internet

\footnotetext{
${ }^{16}$ Due to possible collinearity among the company size, revenue growth, and profitability variables, the sum of these percentages may overstate the combined explanatory power of these variables in a multivariate context.
} 
Companies) while company size is the dominant contributor for Sample Three (venture-backed private companies).

Table 8 reports for Sample One rank regressions for the (a) positive revenue growth, (b) negative revenue growth, and (c) missing revenue growth observation subsamples in panels $\mathrm{A}$ through $\mathrm{C}$, respectively. The positive revenue growth subsample is the largest subsample and has results similar to Regression \#7 in Table 7. The negative revenue growth subsample has a sign reversal on the two revenue growth independent variables - the coefficient on current revenue growth is significantly negative while the coefficient on future revenue growth is significantly positive. These results support Hypothesis Three and are consistent with the "flipping" of the portfolio revenue growth rates in Year $\mathrm{t}$ and Year $\mathrm{t}+1$ in Figure 5 (Panel B). The missing observations subsample has (by definition) no current revenue growth independent variable; the coefficient on the future revenue growth variable is significantly positive.

The multivariate results in Tables 7 and 8 reinforce the findings reported in prior sections. Revenue growth and company size are key determinants of $\mathrm{MKT}_{\mathrm{t}} / \mathrm{REV}_{\mathrm{t}}$ multiples. Moreover, the capital market is able to distinguish (in a probabilistic sense) cases where both current and future revenue growth are positively correlated from cases where they are negatively correlated.

\section{Overview and Extensions Of Research}

Our findings have implications for research in at least four areas - capital market valuation, "management" of reported financial numbers, analysis of the 1998-2000 capital market "bubble era", and early-stage company valuation and growth.

\section{Capital Market Valuation Research}


Prior capital market research has recognized that deleting observations with negative net income or negative book value results in samples under-represented in:
a.) high-technology companies, and
b.) younger early-stage companies

The samples examined in this paper include a broad cross-section of (a) and (b) companies as well as companies from other industries and in their post early-stages. We document several marked features of (a) and (b) companies. Such companies typically have higher revenue growth rates, higher variability in revenue growth rates, and a higher negative income likelihood. The strong support for our Hypothesis One (negative association between $M K T_{t} / R V_{t}$ and company size) and Hypothesis Two (positive association between $\mathrm{MKT}_{\mathrm{t}} / \mathrm{REV}_{\mathrm{t}}$ and recent positive revenue growth) highlights the importance of recognizing company size and revenue growth variables in company valuation research. Note, moreover, that these variables are also highly statistically significant in a broad sample of non-high technology publicly traded companies (Sample One All Other Companies).

Our analysis is of increased interest in the post-"internet bubble" period given the continued high profile valuation of select individual early-stage companies e.g., Facebook (2004/2005 startup), Zynga (2007 startup), and Groupon (2008 startup).

\section{Management of Reported Financial Numbers Research}

The earnings management literature hypothesizes that management proactively uses accounting rules (such as revenue or expense recognition) to change reported accounting numbers. One explanation for a transitory component in reported numbers is management accounting "adjustments" for reasons related to misrepresenting underlying economics e.g., changing software revenue recognition assumptions to maximize a compensation bonus or an earn-out provision. However, other explanations (of a non-management manipulation kind) for the transitory component exist - e.g., a negative transitory revenue component could be due to a delay in a recurring computer hardware sales shipment cycle due to an unexpected shortage of 
component parts. In some cases, a negative transitory revenue component in Year t may well result in a positive transitory revenue component in Year $t+1$. Research on ways to better identify contexts where transitory revenue is sizable (and their possible explanations) can assist the probing of earnings "management" hypotheses. The research in this paper used the joint combination of (i) a high $\mathrm{MKT}_{\mathrm{t}} / \mathrm{REV}_{\mathrm{t}}$ multiple, and (ii) a negative current revenue growth to identify negative transitory revenue contexts. Alternative combinations of $\mathrm{MKT}_{t} / \mathrm{REV}_{\mathrm{t}}$ levels and revenue growth rates could potentially be used to identify positive transitory revenue contexts. Note that a key assumption here is that the capital market is able to identify (in a relatively high probabilistic sense) this transitory component when setting $\mathrm{MKT}_{t} / \mathrm{REV}_{\mathrm{t}}$ multiples.

\section{Analysis of 1998-2000 Capital Market "Bubble Era"}

The working assumption in many descriptions of the 1998-2000 capital market period is that company fundamentals did not explain the historically high levels of market multiples. Our research looks at both the pre and post behavior of revenue growth and documents their dramatic decline in 2000/2001 vis-à-vis 1998-2000. We document that industries with the largest increases/decreases in market capitalization in the 1998-2001 period had characteristics that identified them as relatively high risk for an extended period prior to 1998 e.g., higher beta, higher standard deviation of security returns, and higher percentage of negative net income. Our results are consistent with capital markets behaving more rationally along the predictions of capital market theory than many observers are willing to recognize.

Our results also highlight that the capital market 1998-2000 surge and subsequent decline in valuations was not restricted to the so-called internet companies that have been the focus of many research studies. While internet companies exhibited very high positive (negative) rates of returns in the 1998-2000 (2000-2001) period, the dollar amount of their aggregate market capitalization increase/decrease is dwarfed by the aggregate increase/decrease in market capitalization of our Selected SIC Industries group, which comprise the broader computer software/hardware/telecommunications/biotech-pharmaceuticals sectors. Aggregate market 
capitalizations of our Selected SIC Industries group and the Internet Companies are (from Table 1

- $\$$ billions $\left.{ }^{17}\right)$ :

\begin{tabular}{|c|c|c|c|}
\hline & $\begin{array}{c}\text { Selected SIC } \\
\text { Industries }\end{array}$ & $\begin{array}{c}\text { Internet } \\
\text { Companies }\end{array}$ & $\begin{array}{c}\text { Selected SIC Industries } \\
\text { Excluding Overlapping } \\
\text { Internet Companies }\end{array}$ \\
\hline Aggregate Market Capitalizations & $\$ 2,489$ & $\$ 80$ & \\
$1 / 1 / 1998$ & 9,262 & 1,630 & $\$ 2,412$ \\
$3 / 10 / 2000$ & 4,593 & 279 & 7,762 \\
$12 / 31 / 2001$ & $\$ 6,773 \uparrow$ & $\$ 1,550 \uparrow$ & 4,337 \\
\hline Aggregate Changes & $4,669 \downarrow$ & $1,351 \downarrow$ & $\$ 5,350 \uparrow$ \\
$1 / 1 / 1998-3 / 10 / 2000$ & & $3,425 \downarrow$ \\
\hline
\end{tabular}

Research probing the 1998-2001 capital market era needs to examine a broader set of companies than just those labeled as "internet stocks". Most internet companies were listed on NASDAQ. Many of the companies in our Selected SIC Industries group were listed on the NYSE. The above market capitalization changes highlight that the so-called "internet bubble" is an overly narrow description. The increases/decreases in market capitalization in the 1998-2001 period occurred for many non-internet companies and for many non-NASDAQ companies.

\section{Early-Stage Company Research}

Our research documents that both company size and revenue growth are statistically significant independent variables in $\mathrm{MKT}_{\mathrm{t}} / \mathrm{REV}_{\mathrm{t}}$ models in both public and private markets. We also find the dramatically higher revenue growth rates for our venture-backed private companies sample (Sample Three) vis-à-vis the revenue growth rates for the publicly traded company samples (Samples One and Two) - see Figure 4. Not all early-stage companies are venture capital backed. Venture capitalists traditionally restrict themselves to companies that both address large markets and have the capacity to grow rapidly. The revenue growth rates we report in Figure 4 and Table 4 are consistent with multiple early-stage private companies achieving revenue growth rates not accomplished by many publicly-traded companies. Subsequent research could examine the growth rates on non-venture financed private companies. Such analysis could be part of a broader focus on factors that explain the level and change in revenue growth rates as a company evolves

${ }^{17}$ Table 1 reports the extent to which our Selected SIC Industries and Internet Companies overlap. 
over time. Our research highlights that the existence of venture capital financing likely is a facilitator of high revenue growth. Other potential variables that could be examined include the product/service markets targeted by a company and the experience/aspirations of the management team.

The growing analysis of early-stage companies offers many avenues to analyze how key factors affect company valuation and growth e.g., the type of private financing, the role of public listing, the chosen business model and its ability to scale, and the adoption of management control systems. The dramatic time-series and cross-sectional variations in both the capital market variables and the fundamental accounting variables across both the public and private company samples examined in this paper highlight the fruitful opportunities for subsequent research.

Early-stage companies are also of much interest due to many having a relatively high intangible asset composition vis-à-vis tangible assets. Venture capital funding often occurs because companies have negative net cash flows due to their making "investments" in intangibles such as technologies, discoveries, etc. or the buildup of a sales/marketing capability. Revenues are an important signal that such "investments" are being commercially valued by customers or partners. Rapid growth in revenues potentially is a lead indicator of subsequent growth in profitability. An important research area is understanding the strength, time-horizon and determinants of such lead/lag relationships between revenue growth and profitability growth. 


\section{APPENDIX A}

\section{Risk Differences Across NYSE/AMEX/NASDAQ Subsamples of Listed Companies}

The Selected SIC Industries and All Other Companies subsamples of Sample One exhibit sizable differences in risk-related indicators prior to and after, as well as during, the $1998-2001$ period.

Capital Market Risk: Two frequently used measures of a company's capital market risk are the CAPM beta and the standard deviation of security returns. The Selected SIC Industries group has had higher relative market risk and higher total market risk than the All Other Companies group for an extended time period since the 1980's through to 2004:

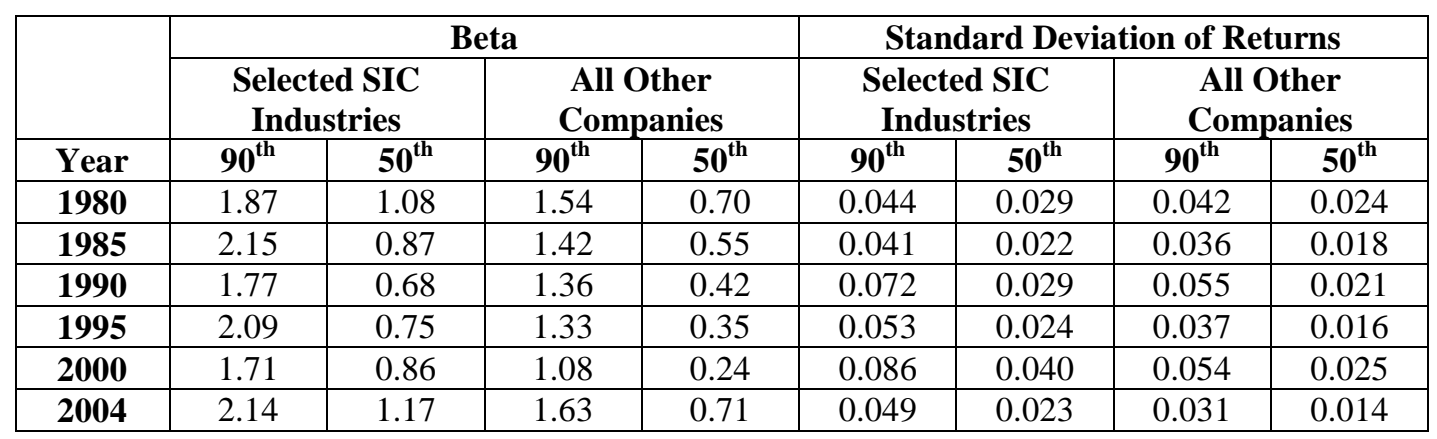

These data highlight that before, during, and after the 1998-2001 period, our Selected SIC Industry group had sizably higher market relative risk and higher market total risk than our All Other Companies group. With this higher risk, finance theory would predict came the potential for larger increases in market capitalization and larger decreases in market capitalization.

Negative Net Income: A fundamental indicator of company risk is the likelihood of reporting a loss. All else held equal, a firm with negative net income is less likely to generate funds for investing in new growth opportunities or to make distributions to its shareholders. The Selected SIC Industries group differs markedly from the All Other Companies group in terms of its propensity for losses. While there has been an increase since 1980 in the percentage of all 
companies reporting negative net income (with a decline in the 2002 to 2004 period), this increase has been concentrated in our Selected SIC Industries group:

\begin{tabular}{|c|c|c|c|}
\hline Year & $\begin{array}{c}\text { Selected } \\
\text { SIC Industries }\end{array}$ & $\begin{array}{c}\text { All Other } \\
\text { Industries }\end{array}$ & $\begin{array}{c}\text { All Companies } \\
\text { Pooled }\end{array}$ \\
\hline $\mathbf{1 9 8 0}$ & $7.8 \%$ & $23.5 \%$ & $21.5 \%$ \\
\hline $\mathbf{1 9 8 5}$ & $30.3 \%$ & $16.3 \%$ & $18.5 \%$ \\
\hline $\mathbf{1 9 9 0}$ & $37.2 \%$ & $23.1 \%$ & $25.6 \%$ \\
\hline $\mathbf{1 9 9 5}$ & $39.1 \%$ & $17.2 \%$ & $21.9 \%$ \\
\hline $\mathbf{2 0 0 0}$ & $56.8 \%$ & $22.3 \%$ & $31.0 \%$ \\
\hline $\mathbf{2 0 0 1}$ & $68.0 \%$ & $25.3 \%$ & $36.0 \%$ \\
\hline $\mathbf{2 0 0 4}$ & $50.3 \%$ & $22.7 \%$ & $29.4 \%$ \\
\hline
\end{tabular}

The results for the All Companies column have been noted before by Hayn [1995], Collins, Pincus, and Xie [1999], and Joos and Plesko [2005]. Over time, the likelihood that a publiclytraded U.S. listed company will report a loss has increased. In 1980, there was roughly a $20 \%$ chance in any one year, while by 2000 there was more than a $30 \%$ chance. ${ }^{18}$

Companies on NASDAQ have higher loss percentages than companies on the NYSE/AMEX. Selected percentages over the 1980 to 2000 period are:

\begin{tabular}{|c|c|c|c|}
\hline Year & $\begin{array}{c}\text { NASDAQ } \\
\text { Companies }\end{array}$ & $\begin{array}{c}\text { NYSE/AMEX } \\
\text { Companies }\end{array}$ & $\begin{array}{c}\text { All } \\
\text { Companies }\end{array}$ \\
\hline $\mathbf{1 9 8 0}$ & $23.6 \%$ & $21.3 \%$ & $21.5 \%$ \\
\hline $\mathbf{1 9 8 5}$ & $21.5 \%$ & $16.7 \%$ & $18.5 \%$ \\
\hline $\mathbf{1 9 9 0}$ & $31.5 \%$ & $21.5 \%$ & $25.6 \%$ \\
\hline $\mathbf{1 9 9 5}$ & $27.5 \%$ & $15.7 \%$ & $21.9 \%$ \\
\hline $\mathbf{2 0 0 0}$ & $40.5 \%$ & $18.3 \%$ & $31.0 \%$ \\
\hline $\mathbf{2 0 0 1}$ & $44.1 \%$ & $25.5 \%$ & $36.0 \%$ \\
\hline $\mathbf{2 0 0 4}$ & $36.4 \%$ & $20.3 \%$ & $29.4 \%$ \\
\hline
\end{tabular}

NASDAQ companies are, on average, smaller and younger than companies on the NYSE/AMEX.

Size and age have been found to useful predictors of financial distress [Altman, 2000].

\footnotetext{
${ }^{18}$ The proposition that the percentage of losses has increased over time is supported by a univariate regression of the percentage loss on a time trend. The trend term is positive and significant. Fama and French [2004] report evidence of an increase in loss rates for newly listed companies.
} 
Figure 1

Market Capitalization to Revenue Multiple Percentiles $\left(90^{\text {th }}, \mathbf{7 0}^{\text {th }}, \mathbf{5 0}^{\text {th }}, \mathbf{3 0}^{\text {th }}\right.$, and $\left.\mathbf{1 0}^{\text {th }}\right)$ for Sample One (All NYSE/AMEX/NASDAQ Public Companies), Sample Two (Internet Public Companies) and Sample Three (Venture-Backed Private Companies): 1980 to 2004

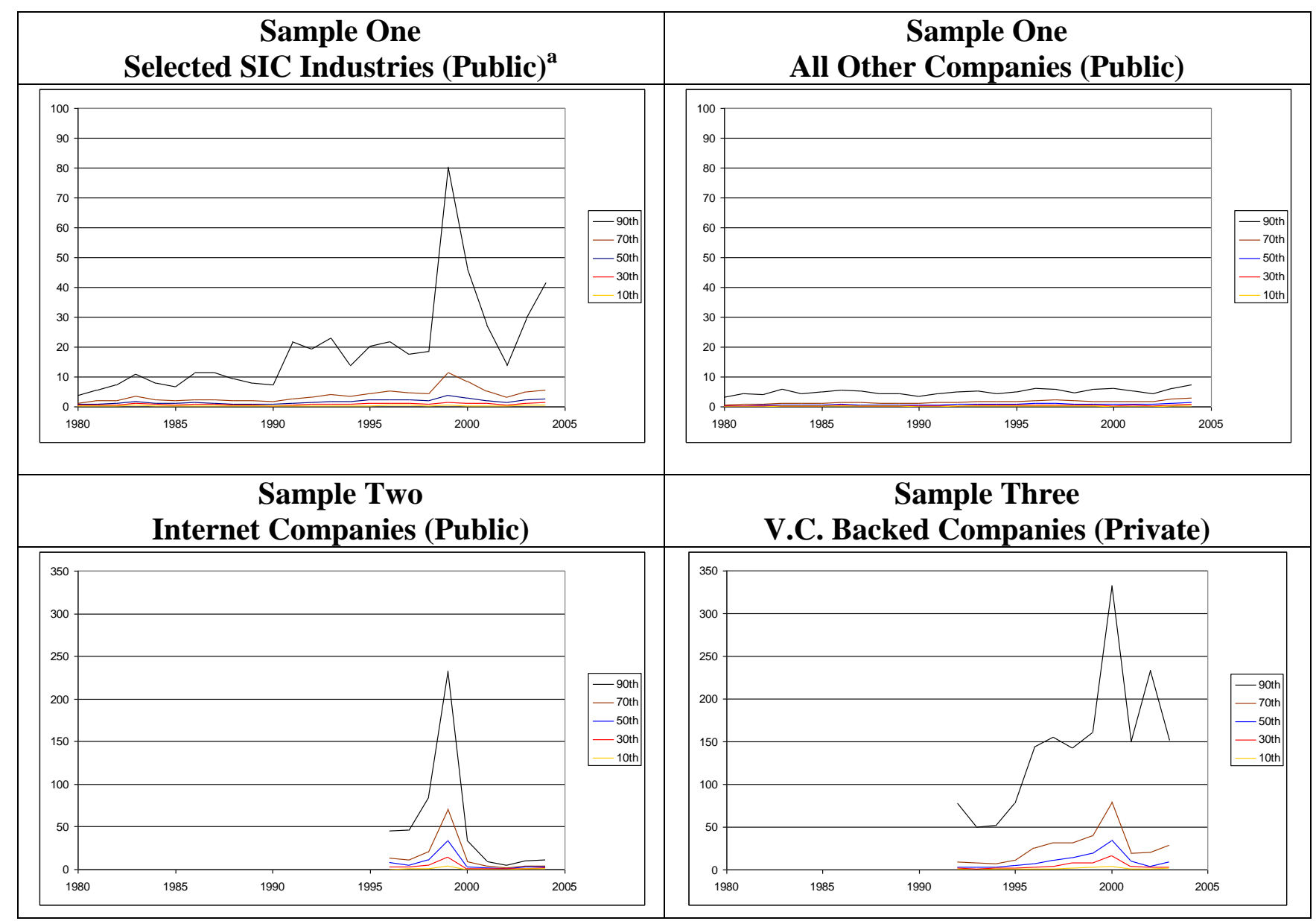

a. Comprises companies in Hardware, Software, Telecom, and Biotech/Pharmaceuticals Industries 
Figure 2 - Panel A

Annual Market Capitalization-to-Revenue Multiple Percentiles for Sample One Companies in Selected SIC Industries for Various Company Size Categories: 1980 - 2004

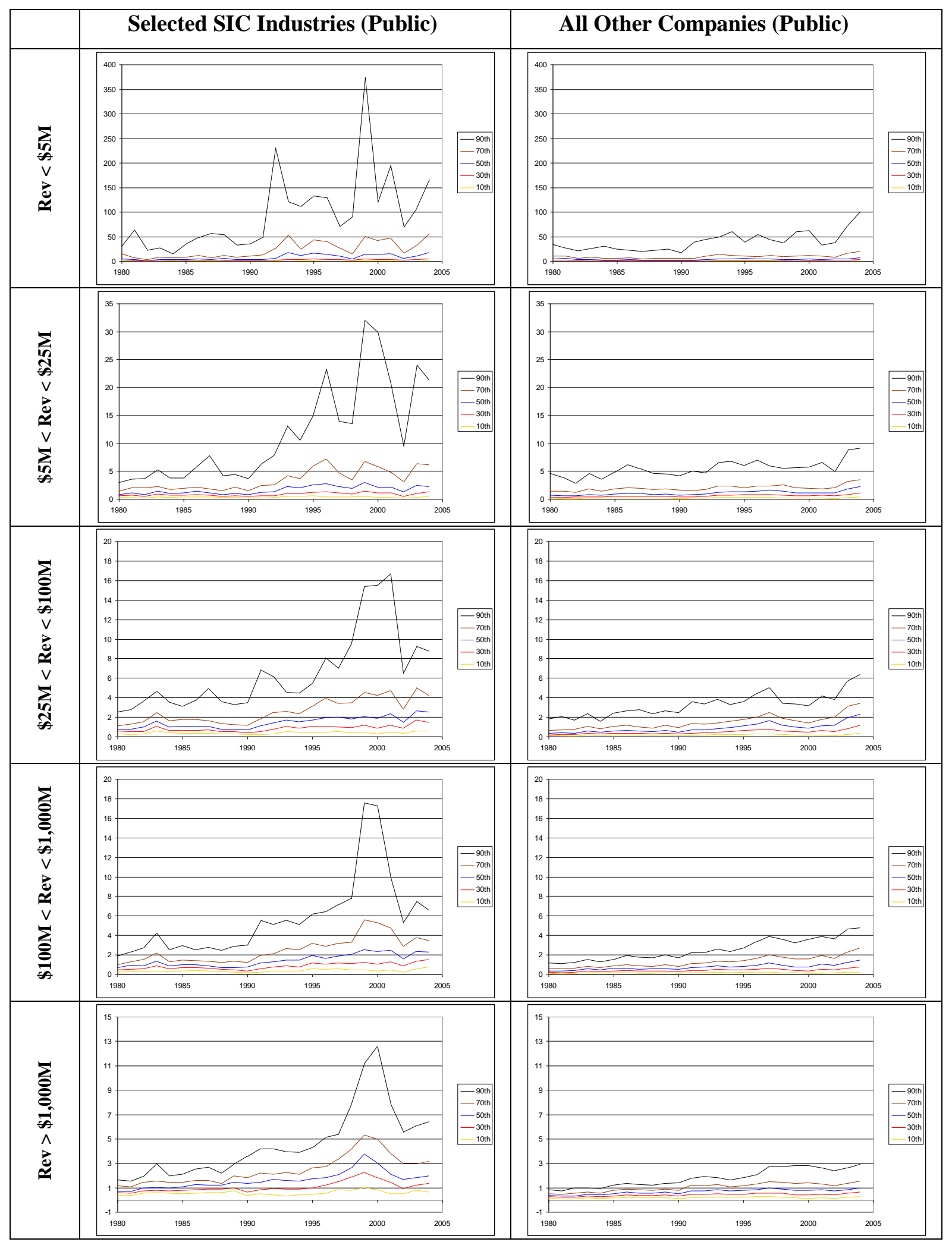


Figure 2 - Panel B

Annual Market Capitalization-to-Revenue Multiple Percentiles for Sample Two and Sample Three Companies for Various Company Size Categories: 1980 - 2004

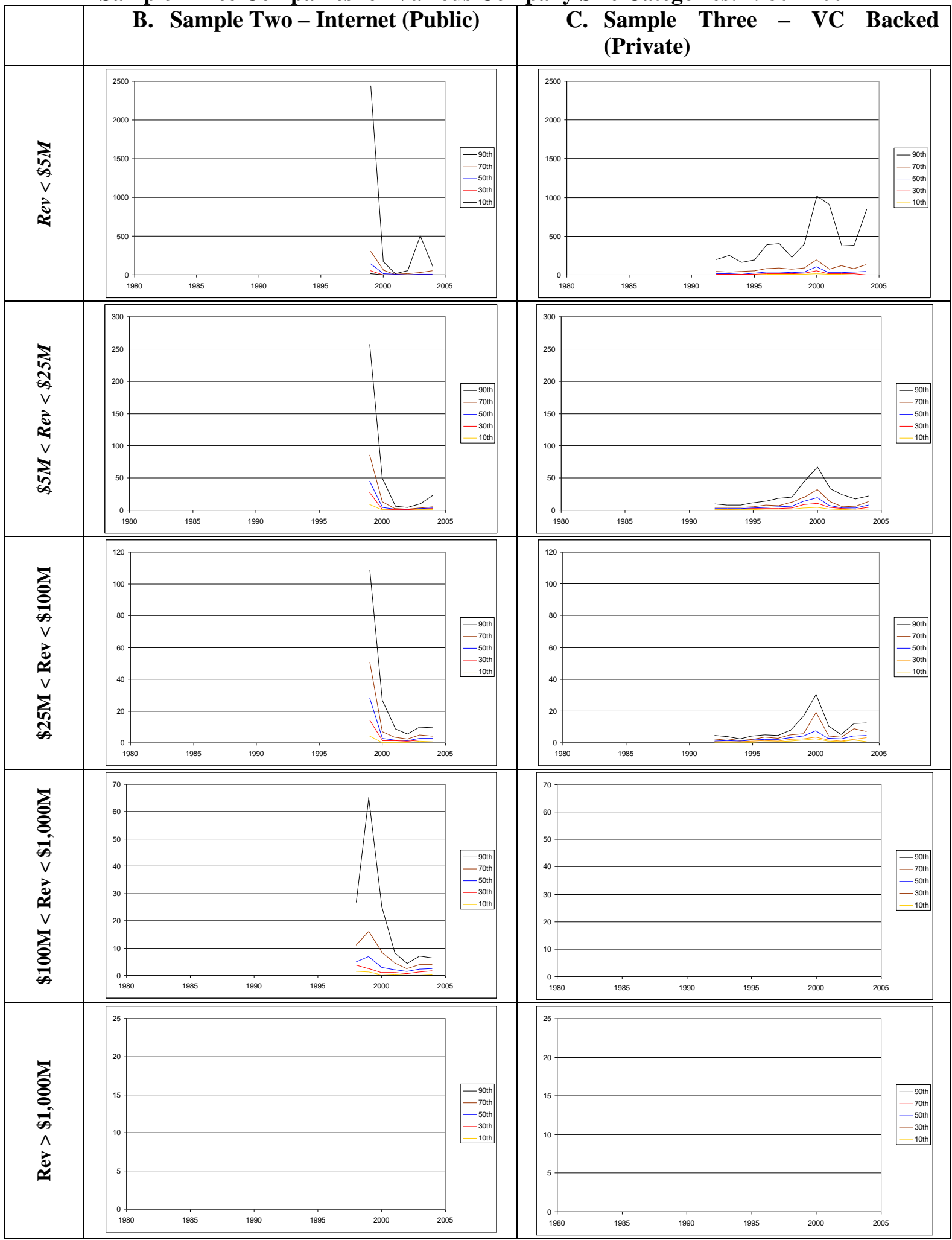


Figure 3

Annual Revenue Growth Percentiles $\left(10^{\text {th }}, 30^{\text {th }}, 5^{\text {th }}, \mathbf{7 0}^{\text {th }}\right.$, and $\left.90^{\text {th }}\right)$ and Interdecile Range $\left(90^{\text {th }}-10^{\text {th }}\right)$ for Publicly Traded Companies on NYSE/AMEX/NASDAQ: 1980 to 2004

Panel A: Selected SIC Industries (Hardware, Software, Telecom, Biotech/Pharma)

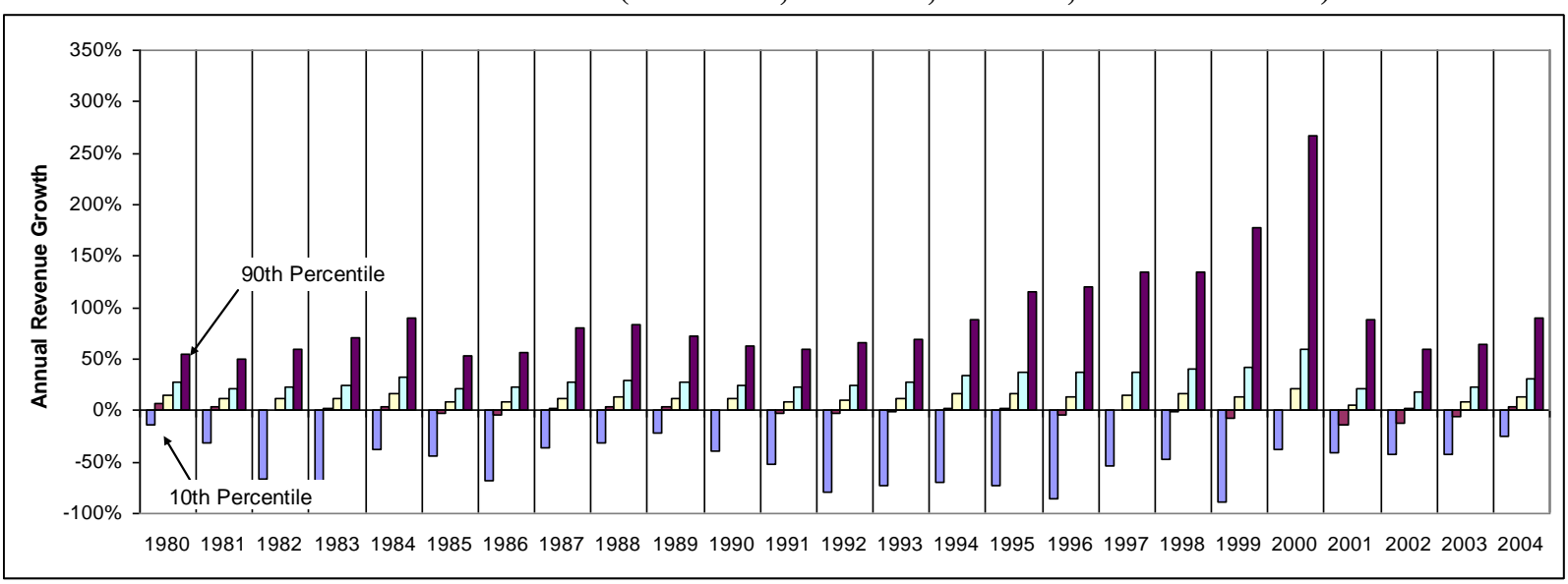

Panel B: All Other Companies

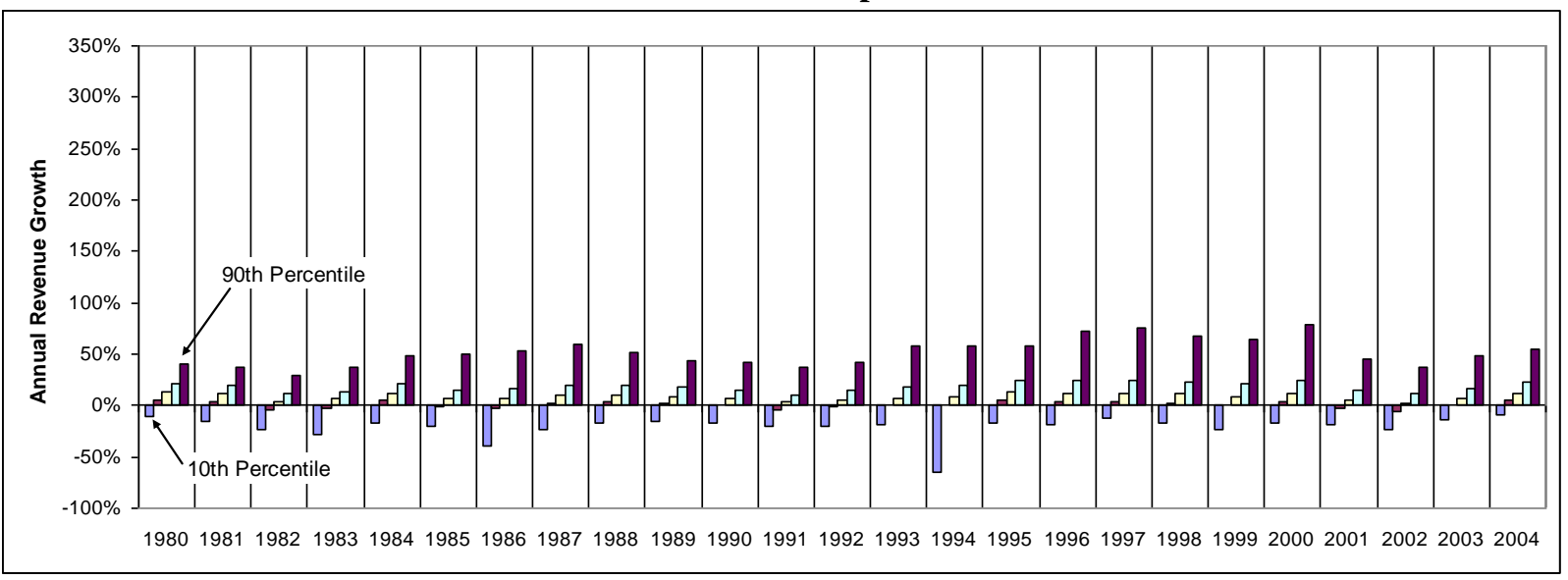

Panel C: Annual Interpercentile $\left(90^{\text {th }}-10^{\text {th }}\right)$ Range

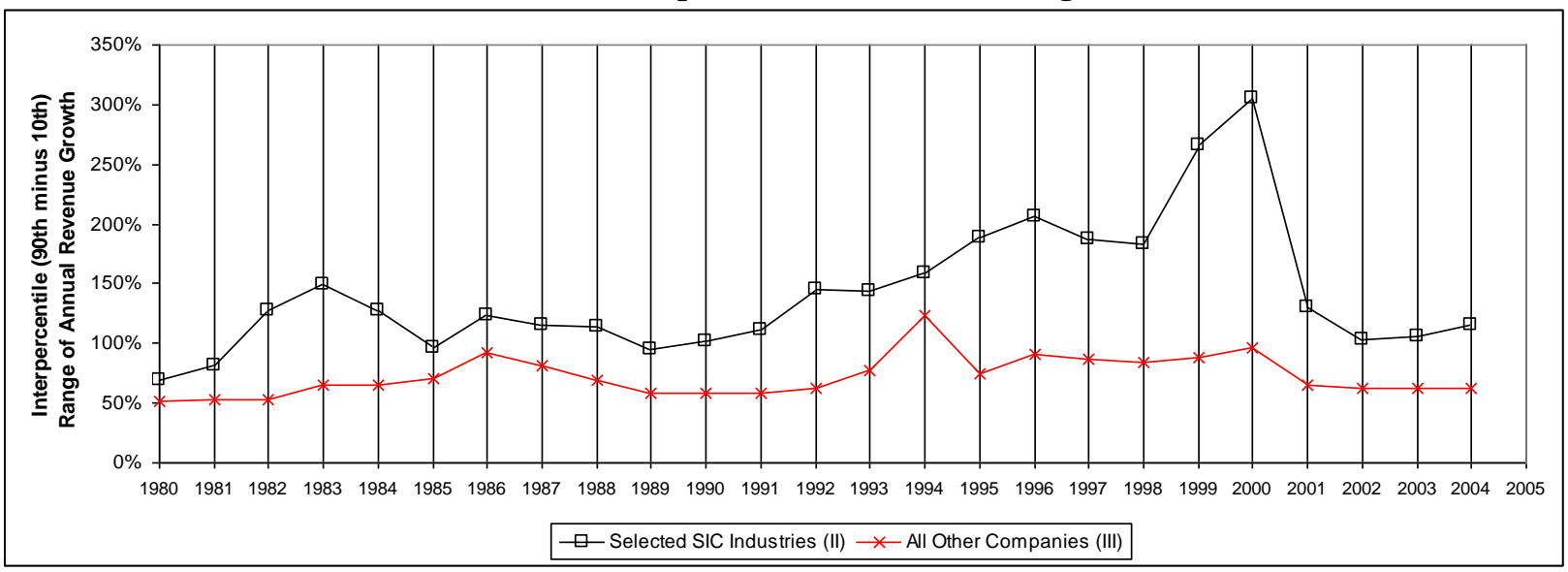


Figure 4

Annual Revenue Growth Rates For Publicly-Traded Companies and Private Venture-Backed Companies: 1996 - 2004 Selected SIC Industries vs. All Other Companies vs. Internet Companies vs. Venture-Backed Companies

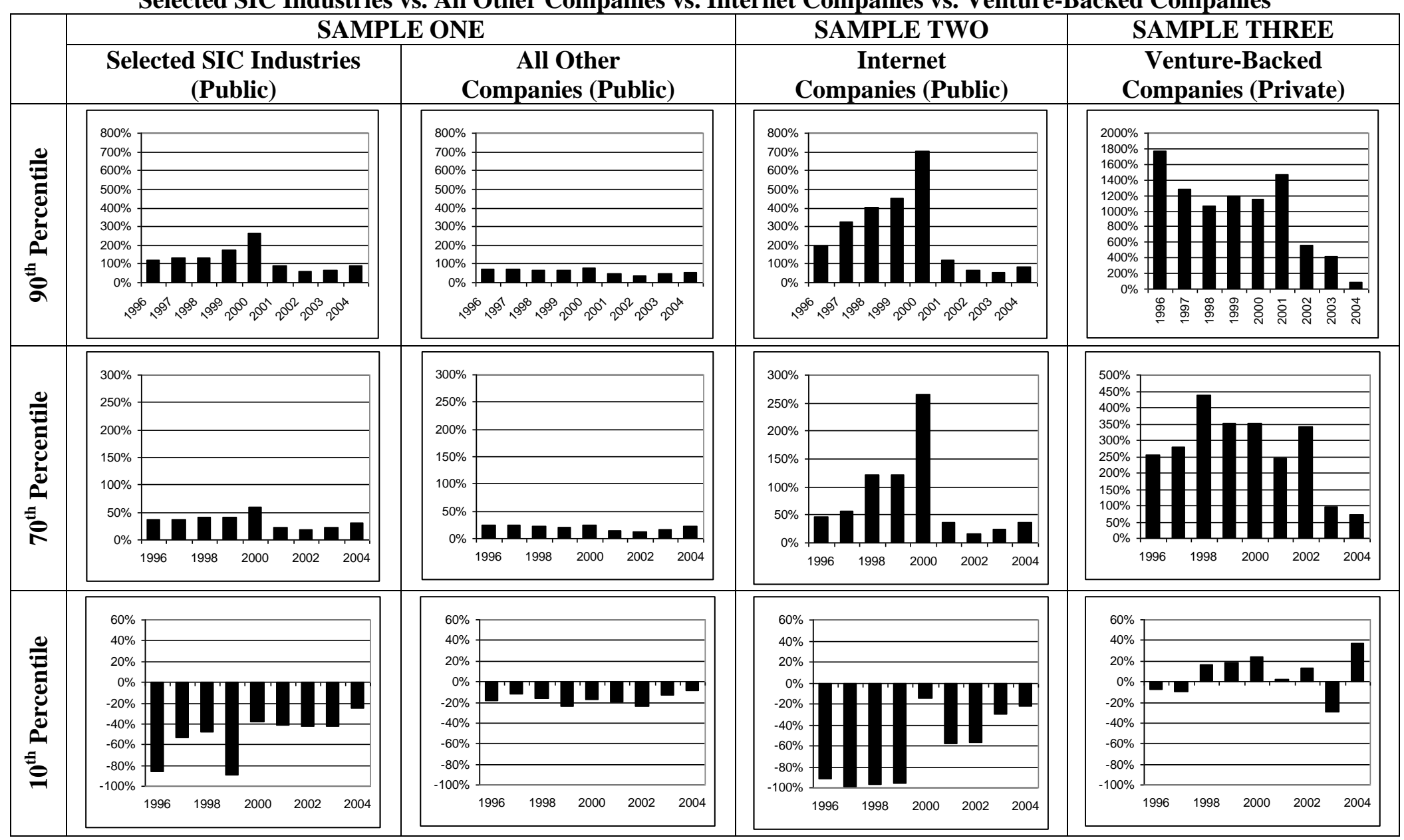


Figure 5 - Panel A

Median Annual Portfolio Revenue Growth in Years $t, t+1$, and $t+2$ for Portfolios Formed Using MKT $/ \mathbf{R E V}_{\mathbf{t}}$ Rankings: 10 Portfolios with Positive Revenue Growth in Year $\mathbf{t}$

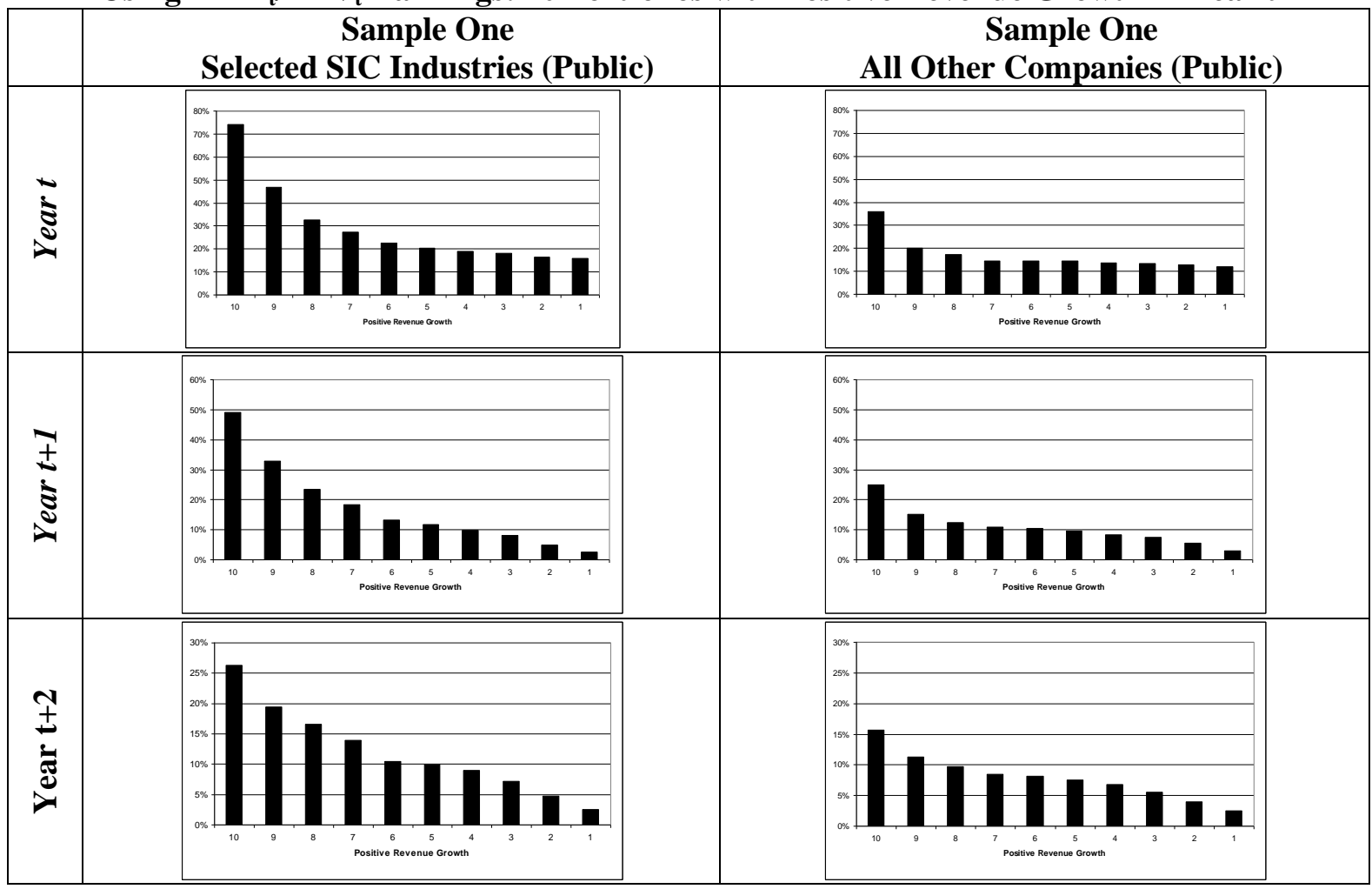

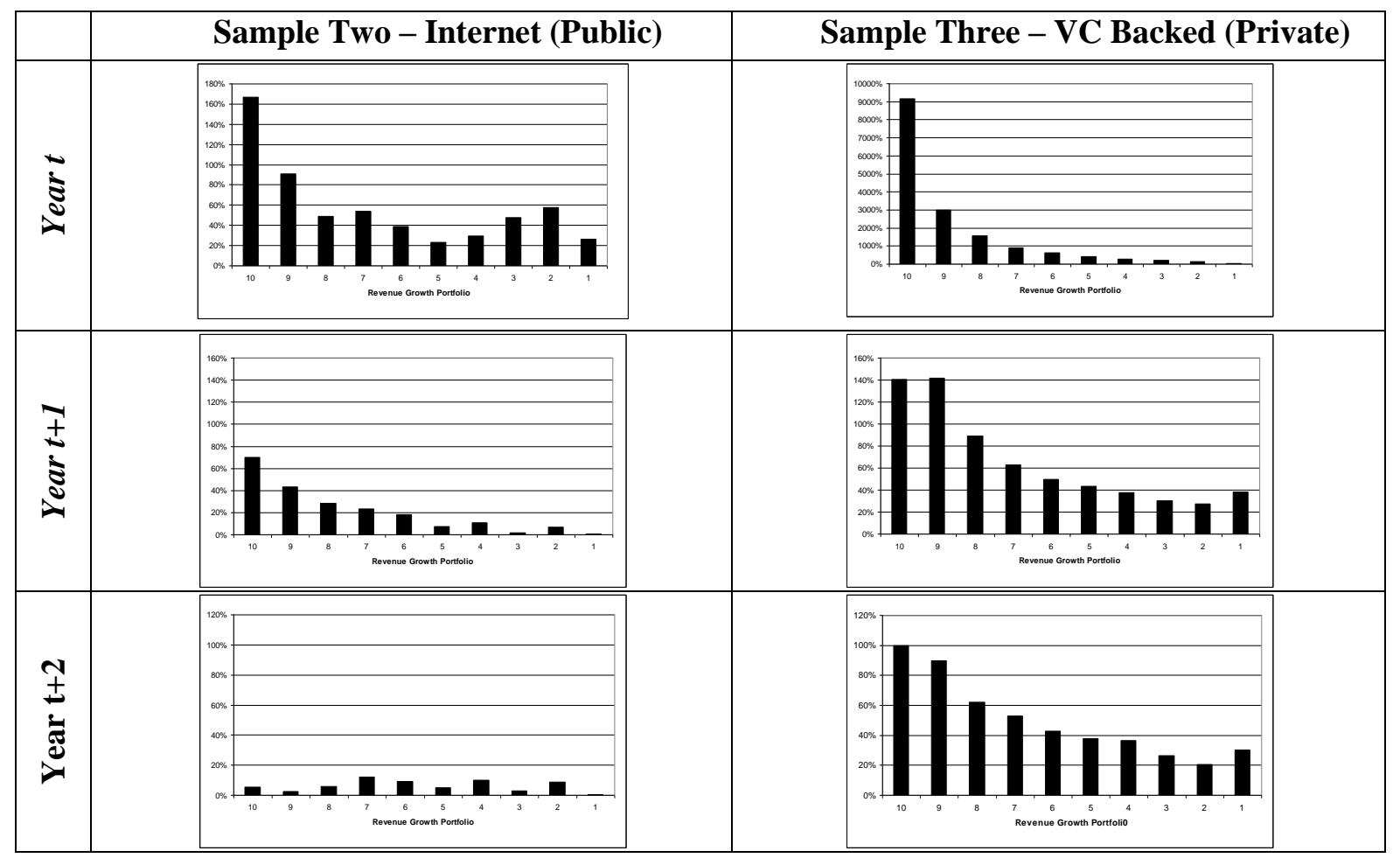


Figure 5 - Panel B

Median Annual Portfolio Revenue Growth in Years $t, t+1$, and $t+2$ for Portfolios Formed Using MKT $/ \mathbf{R E V}_{\mathbf{t}}$ Rankings: 10 Portfolios with Negative Revenue Growth in Year $\mathbf{t}$

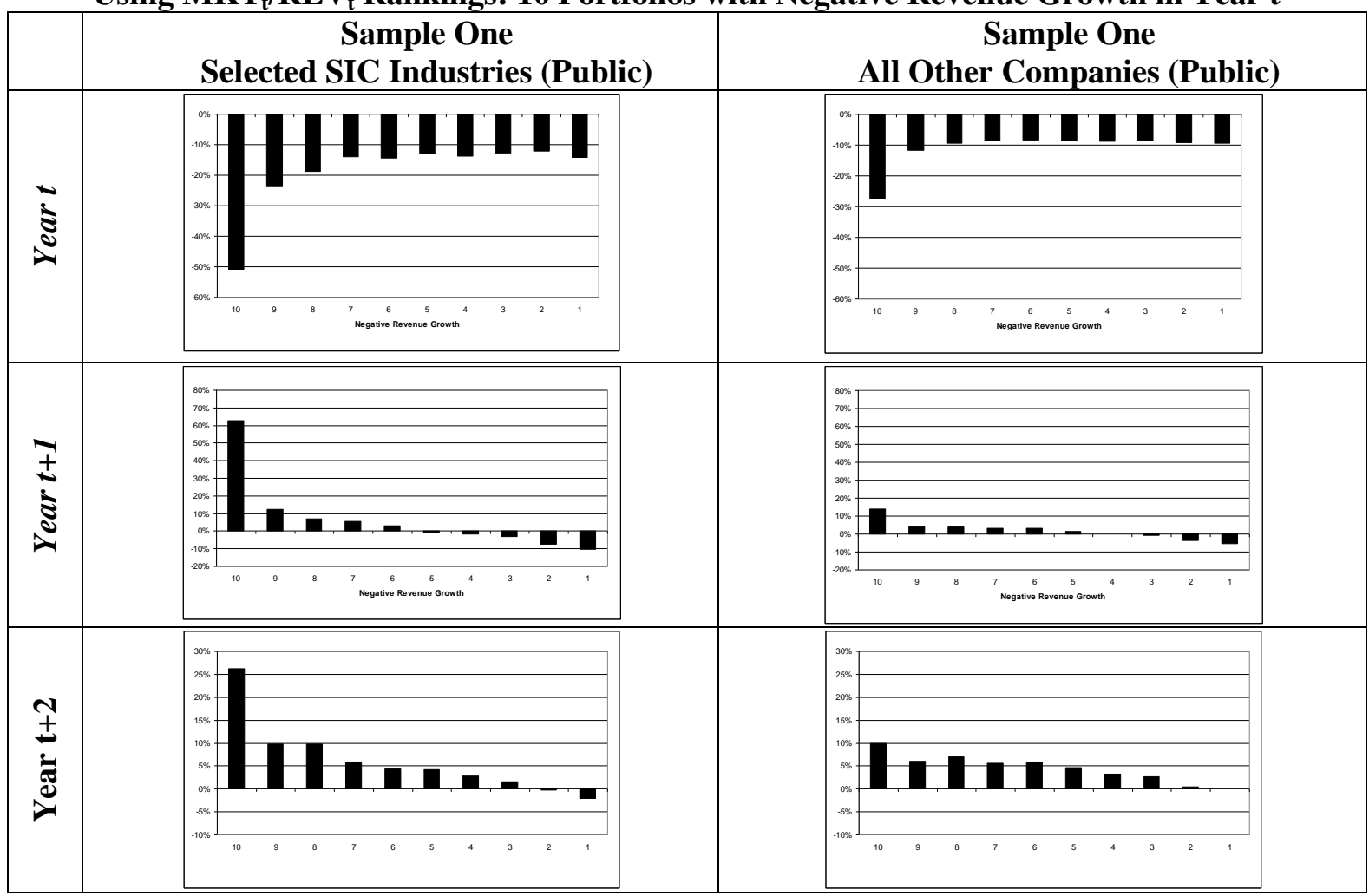

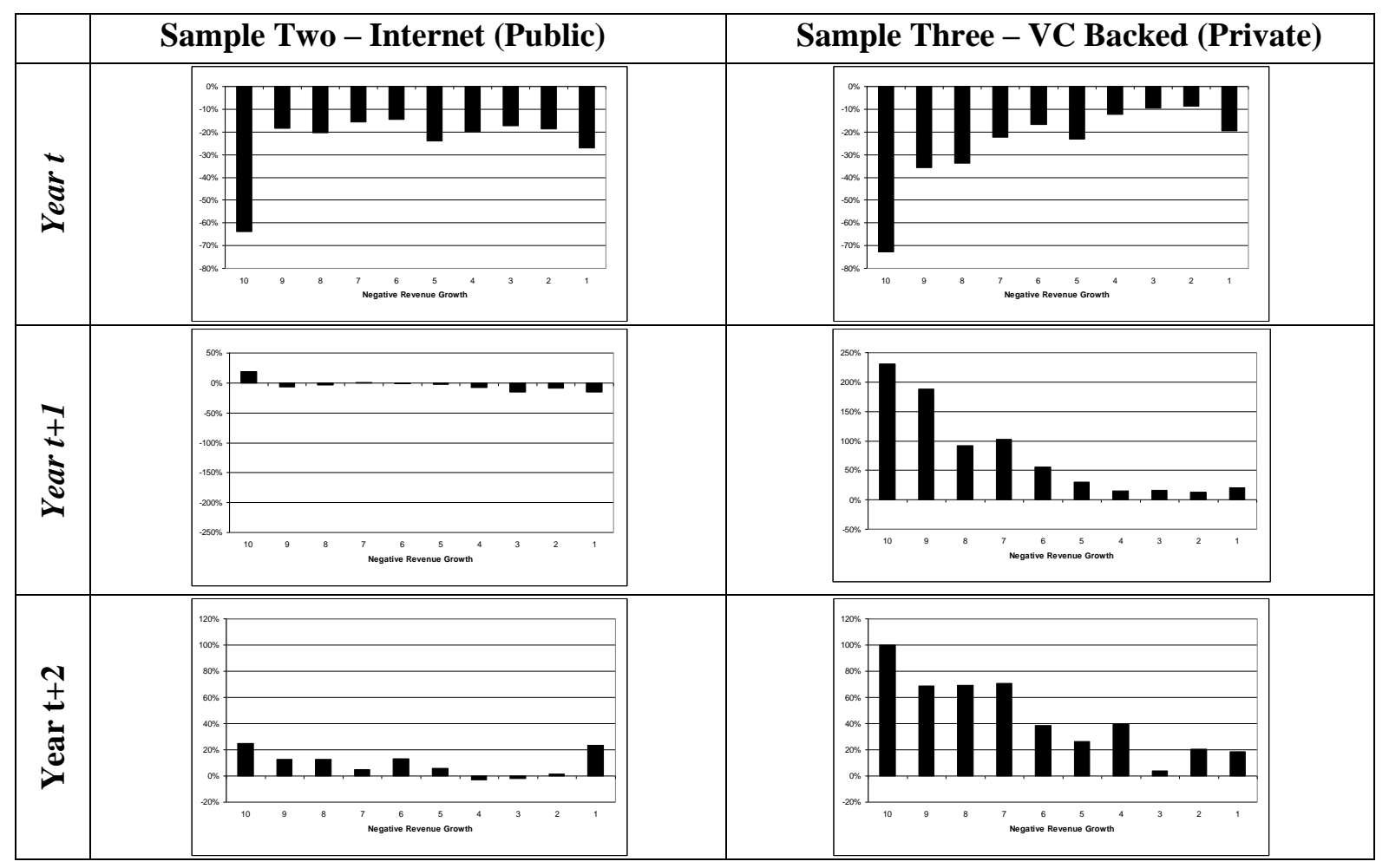




\section{Table 1}

\section{Summary Statistics on Three Samples: Sample One (All NYSE/AMEX/NASDAQ Public Companies), Sample Two (Internet Public Companies) and Sample Three (Venture- Backed Private Companies).}

\section{Panel A}

\begin{tabular}{|c|c|c|c|c|}
\hline & \multicolumn{3}{|c|}{ Aggregate Market Capitalization (\$ Billions) } & \multirow{2}{*}{$\begin{array}{l}\text { No. of Companies } \\
3 / 10 / 2000 \\
\end{array}$} \\
\hline Sample One - NYSE/AMEX/NASDAQ Companies (Public) & \begin{tabular}{l|l}
$1 / 1 / 1998$ \\
\end{tabular} & $3 / 10 / 2000$ & $12 / 31 / 2001$ & \\
\hline I. All Companies & $\$ 11,051$ & $\$ 18,398$ & $\$ 14,212$ & 8,401 \\
\hline $\begin{array}{l}\text { II. Pooled Selected SIC Industries } \\
(357,366,367,737,481,283)\end{array}$ & 2,849 & 9,262 & 4,593 & 1,932 \\
\hline $\begin{array}{l}\text { II.A. Computer Hardware }(357,366,367) \\
\text { II.B. Computer Software }(737) \\
\text { II.C. Telecommunications }(481) \\
\text { II.D. Biotech/Pharma }(283)\end{array}$ & $\begin{array}{l}933 \\
550 \\
528 \\
839\end{array}$ & $\begin{array}{l}4,098 \\
2,504 \\
1,387 \\
1,273\end{array}$ & $\begin{array}{r}1,612 \\
979 \\
625 \\
1,377\end{array}$ & $\begin{array}{l}615 \\
792 \\
190 \\
335\end{array}$ \\
\hline III. All Other Companies & 8,202 & 9,135 & 9,619 & 6,469 \\
\hline
\end{tabular}

\section{Panel B}

\begin{tabular}{|c|c|c|c|}
\hline & \multicolumn{3}{|c|}{ Aggregate Market Capitalization (\$ Billions) } \\
\hline Sample Two - Internet Companies (Public) & \begin{tabular}{l|l}
$1 / 1 / 1998$ & \\
\end{tabular} & $3 / 10 / 2000$ & $12 / 31 / 2001$ \\
\hline I. All Internet Companies & $\$ 80$ & $\$ 1,630$ & $\$ 279$ \\
\hline II. PooledSelected Internet SIC Industries & 77 & 1,500 & 25 \\
\hline II.A. Internet - Computer Hardware & 57 & 653 & 15 \\
\hline II.B. Internet - Computer Software & 17 & 726 & 72 \\
\hline II.C. Internet - Telecommunications & 2 & 47 & 2 \\
\hline II.D. Internet - Business Services & 1 & 75 & 24 \\
\hline III. All Other Internet Companies & 3 & 130 & 23 \\
\hline
\end{tabular}

\section{Panel C}

\begin{tabular}{|c|c|c|c|}
\hline Sample Three - VC Backed Companies (Private) & \begin{tabular}{l|} 
Number of \\
Companies \\
\end{tabular} & $\begin{array}{c}\text { Number with } \\
\text { IPO } \\
\end{array}$ & $\begin{array}{c}\text { Internet Coy's } \\
\text { with IPO(c) }\end{array}$ \\
\hline I. All VentureOne Companies & 11,910 & 1,262 & 239 \\
\hline I.A. Software (a) & 4,811 & 388 & 134 \\
\hline I.B. Consumer-Business Services & 2,272 & 127 & 48 \\
\hline I.C. Communications & 1,604 & 195 & 53 \\
\hline I.D. Biopharmaceuticals & 1,008 & 23 & 0 \\
\hline I.E. Hardware/Equipment (b) & 2,215 & 32 & 4 \\
\hline
\end{tabular}

(a) Comprises the "Software" and "Information Services" Industry Segments of VentureOne.

(b) Comprises the "Medical Devices," "Electronics," and "Semiconductors" Industry Segments of VentureOne.

(c) The Internet company list (taken from Jay Ritter's website) is combined with the VentureOne listing to identify the VentureOne Internet companies with an IPO. 
Table 2

Mean Autocorrelations for First Differenced Annual Financial Series for Sample One (NYSE/AMEX/NASDAQ Publicly-Traded Companies): 1980-2004

\begin{tabular}{|l|c|c|c|c|}
\hline & $\mathbf{r}_{\mathbf{1}}$ & $\mathbf{r}_{\mathbf{2}}$ & $\mathbf{r}_{\mathbf{3}}$ & $\mathbf{r}_{\mathbf{4}}$ \\
\hline Revenues & & & & \\
$\quad$ Selected SIC Industries & 0.36 & 0.18 & 0.16 & 0.17 \\
All Other Companies & 0.18 & 0.02 & 0.07 & 0.09 \\
\hline Operating Income & & & & \\
$\quad$ Selected SIC Industries & 0.03 & -0.06 & 0.03 & 0.01 \\
$\quad$ All Other Companies & -0.10 & -0.01 & -0.01 & 0.01 \\
\hline Income Before Extraordinary Items & & & & \\
$\quad$ Selected SIC Industries & -0.25 & -0.07 & -0.10 & 0.02 \\
$\quad$ All Other Companies & -0.27 & -0.04 & -0.07 & 0.02 \\
\hline
\end{tabular}


Table 3

\section{Annual Revenue Growth Rate Percentiles $\left(10^{\text {th }}, 20^{\text {th }} \ldots 90^{\text {th }}\right)$ By Company Size Category (\$ Millions: I, \$0-\$5; II, \$5-\$25; III, \$25-\$100; IV, \$100-\$1,000; > \$1,000) For Samples One, Two, and Three}

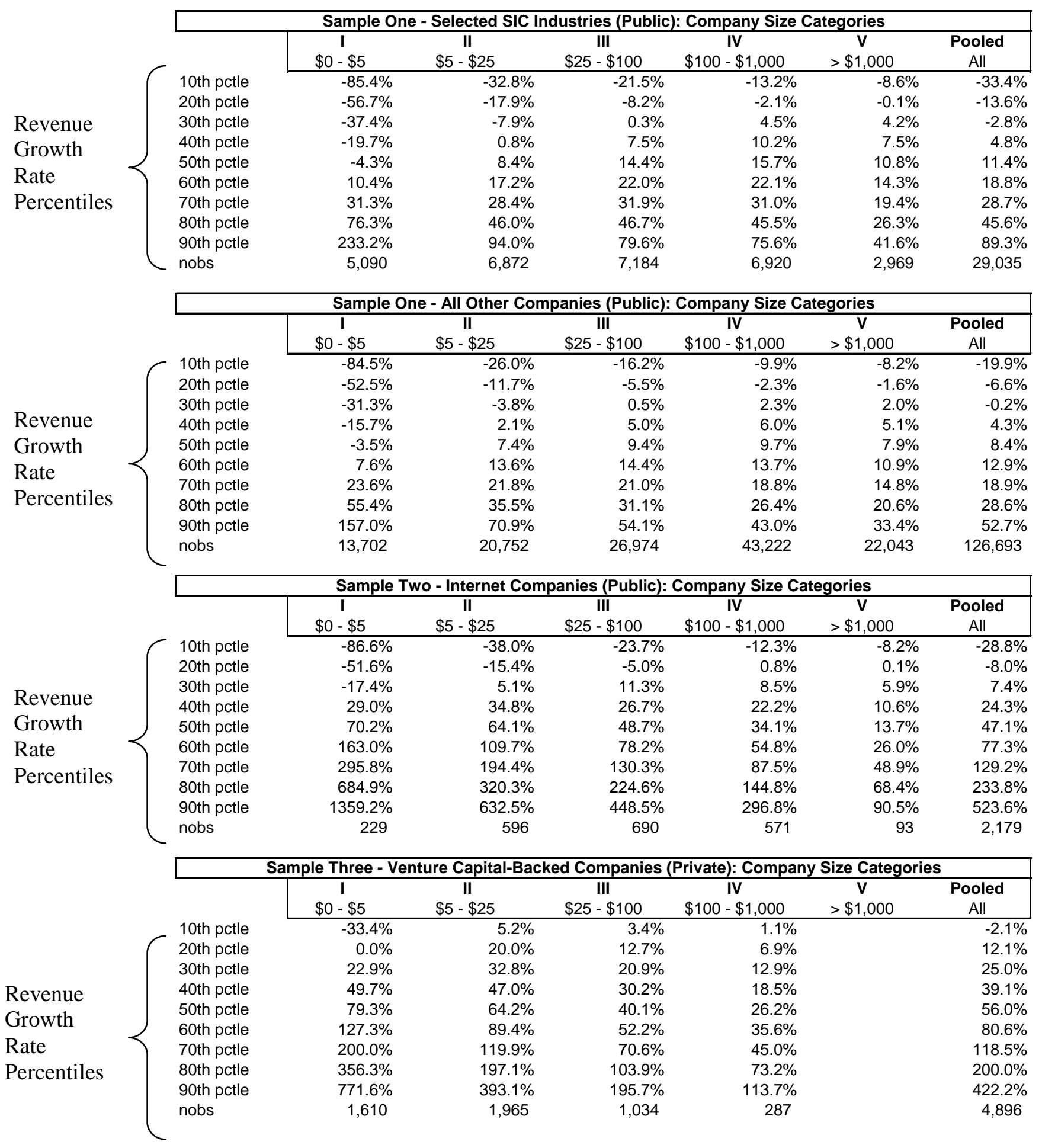


Table 4

$M_{K T} / R_{t} V_{t}$ Multiple Distribution Summary for Subsamples Formed On Sign of Revenue Growth in Year $t$

\begin{tabular}{|c|c|c|c|c|c|c|c|c|c|c|c|c|c|c|c|c|}
\hline \multirow[b]{3}{*}{ Sample One Selected SIC } & \multirow[b]{3}{*}{$\begin{array}{l}\text { Total } \\
\text { Obs. }\end{array}$} & \multicolumn{5}{|c|}{ Positive Revenue Growth Subsample } & \multicolumn{5}{|c|}{ Negative Revenue Growth Subsample } & \multicolumn{5}{|c|}{ Missing Revenue Growth Subsample } \\
\hline & & \multicolumn{3}{|c|}{ MKT/Rev Multiple } & \multirow[b]{2}{*}{ Nob's } & \multirow{2}{*}{$\begin{array}{c}\% \text { of } \\
\text { Total } \\
\text { Sample }\end{array}$} & \multicolumn{3}{|c|}{ MKT/Rev Multiple } & \multirow[b]{2}{*}{ Nob's } & \multirow{2}{*}{$\begin{array}{c}\% \text { of } \\
\text { Total } \\
\text { Sample }\end{array}$} & \multicolumn{3}{|c|}{ MKT/Rev Multiple } & \multirow[b]{2}{*}{ Nob's } & \multirow{2}{*}{$\begin{array}{c}\% \text { of } \\
\text { Total } \\
\text { Sample }\end{array}$} \\
\hline & & $\begin{array}{l}\text { 10th } \\
\text { Perc. }\end{array}$ & $\begin{array}{l}\text { 50th } \\
\text { Perc. }\end{array}$ & $\begin{array}{l}\text { 90th } \\
\text { Perc. }\end{array}$ & & & $\begin{array}{l}\text { 10th } \\
\text { Perc. }\end{array}$ & $\begin{array}{l}\text { 50th } \\
\text { Perc. }\end{array}$ & $\begin{array}{l}\text { 90th } \\
\text { Perc. }\end{array}$ & & & $\begin{array}{l}\text { 10th } \\
\text { Perc. }\end{array}$ & $\begin{array}{l}\text { 50th } \\
\text { Perc. }\end{array}$ & $\begin{array}{l}\text { 90th } \\
\text { Perc. }\end{array}$ & & \\
\hline 1995 & 1484 & 0.5 & 2.3 & 11.2 & 906 & $61.1 \%$ & 0.2 & 1.3 & 52.0 & 275 & $18.5 \%$ & 0.6 & 3.6 & 55.4 & 303 & $20.4 \%$ \\
\hline 1998 & 1962 & 0.5 & 2.2 & 11.8 & 1165 & $59.4 \%$ & 0.3 & 1.2 & 26.4 & 574 & $29.3 \%$ & 0.8 & 5.2 & 80.1 & 223 & $11.4 \%$ \\
\hline 1999 & 2154 & 0.6 & 3.2 & 27.3 & 1182 & $54.9 \%$ & 0.3 & 1.8 & 47.1 & 564 & $26.2 \%$ & 1.7 & 31.6 & 365.8 & 408 & $18.9 \%$ \\
\hline 2000 & 2313 & 0.4 & 2.8 & 26.4 & 1313 & $56.8 \%$ & 0.2 & 1.5 & 45.3 & 582 & $25.2 \%$ & 1.0 & 9.8 & 132.0 & 418 & $18.1 \%$ \\
\hline 2001 & 2168 & 0.5 & 2.8 & 22.3 & 1067 & $49.2 \%$ & 0.2 & 1.4 & 24.1 & 950 & $43.8 \%$ & 0.7 & 6.7 & 145.7 & 151 & $7.0 \%$ \\
\hline 2004 & 1726 & 0.7 & 2.5 & 16.0 & 1146 & $66.4 \%$ & 0.4 & 2.6 & 114.5 & 468 & $27.1 \%$ & 1.2 & 11.7 & $1,277.2$ & 112 & $6.5 \%$ \\
\hline \multicolumn{17}{|l|}{$\begin{array}{l}\text { Sample One } \\
\text { All Other }\end{array}$} \\
\hline 1995 & 6524 & 0.2 & 1.0 & 3.8 & 4453 & $68.3 \%$ & 0.1 & 0.8 & 7.3 & 1193 & $18.3 \%$ & 0.2 & 1.4 & 14.7 & 878 & $13.5 \%$ \\
\hline 1998 & 6767 & 0.2 & 1.1 & 4.0 & 4395 & $64.9 \%$ & 0.1 & 0.8 & 5.6 & 1801 & $26.6 \%$ & 0.3 & 1.8 & 12.3 & 571 & $8.4 \%$ \\
\hline 1999 & 6710 & 0.2 & 0.9 & 4.0 & 4198 & $62.6 \%$ & 0.1 & 0.8 & 6.7 & 1865 & $27.8 \%$ & 0.4 & 2.3 & 104.1 & 647 & $9.6 \%$ \\
\hline 2000 & 6451 & 0.1 & 0.9 & 4.2 & 4526 & $70.2 \%$ & 0.0 & 0.5 & 10.5 & 1461 & $22.6 \%$ & 0.4 & 2.6 & 83.9 & 464 & $7.2 \%$ \\
\hline 2001 & 6075 & 0.2 & 1.1 & 4.8 & 3394 & $55.9 \%$ & 0.1 & 0.6 & 4.5 & 2322 & $38.2 \%$ & 0.3 & 2.0 & 132.3 & 359 & $5.9 \%$ \\
\hline 2004 & 4966 & 0.3 & 1.5 & 5.7 & 3642 & $73.3 \%$ & 0.2 & 1.5 & 12.0 & 1067 & $21.5 \%$ & 0.7 & 4.3 & 330.3 & 257 & $5.2 \%$ \\
\hline \multicolumn{17}{|l|}{$\begin{array}{c}\text { Sample Two } \\
\text { Internet }\end{array}$} \\
\hline 1995 & 17 & 0.4 & 1.4 & 8.7 & 10 & $58.8 \%$ & & & & & $0.0 \%$ & 1.0 & 23.5 & $2,101.6$ & 7 & $41.2 \%$ \\
\hline 1998 & 69 & 1.6 & 6.1 & 28.0 & 33 & $47.8 \%$ & 0.1 & 4.3 & 10.5 & 9 & $13.0 \%$ & 4.3 & 24.4 & 91.7 & 27 & $39.1 \%$ \\
\hline 1999 & 275 & 2.1 & 11.9 & 113.6 & 50 & $18.2 \%$ & 0.6 & 2.0 & 37.2 & 11 & $4.0 \%$ & 6.8 & 44.5 & 282.3 & 214 & $77.8 \%$ \\
\hline 2000 & 379 & 0.3 & 2.4 & 20.6 & 207 & $54.6 \%$ & 0.1 & 1.3 & 60.9 & 15 & $4.0 \%$ & 0.9 & 6.9 & 67.1 & 157 & $41.4 \%$ \\
\hline 2001 & 319 & 0.4 & 2.4 & 10.4 & 175 & $54.9 \%$ & 0.2 & 1.5 & 4.9 & 124 & $38.9 \%$ & 0.6 & 3.6 & 12.7 & 20 & $6.3 \%$ \\
\hline 2004 & 202 & 0.8 & 3.0 & 11.0 & 139 & $68.8 \%$ & 0.5 & 2.3 & 23.4 & 59 & $29.2 \%$ & 1.0 & 1.9 & 30.5 & 4 & $2.0 \%$ \\
\hline \multicolumn{17}{|l|}{$\begin{array}{c}\text { Sample Three } \\
\text { v.c. Private Backed }\end{array}$} \\
\hline 1995 & 262 & 0.7 & 3.8 & 17.7 & 186 & $71.0 \%$ & 0.8 & 13.0 & 190.0 & 22 & $8.4 \%$ & 1.2 & 26.4 & 203.3 & 54 & $20.6 \%$ \\
\hline 1998 & 274 & 1.7 & 10.0 & 60.0 & 147 & $53.6 \%$ & 2.1 & 14.5 & 211.1 & 15 & $5.5 \%$ & 4.8 & 27.6 & 300.0 & 112 & $40.9 \%$ \\
\hline 1999 & 361 & 2.6 & 16.5 & 83.2 & 238 & $65.9 \%$ & 3.5 & 16.3 & 600.0 & 25 & $6.9 \%$ & 2.1 & 34.3 & 648.5 & 98 & $27.1 \%$ \\
\hline 2000 & 254 & 3.5 & 24.2 & 160.8 & 150 & $59.1 \%$ & 4.9 & 81.5 & 739.0 & 17 & $6.7 \%$ & 3.8 & 56.2 & $1,971.1$ & 87 & $34.3 \%$ \\
\hline 2001 & 107 & 1.5 & 5.3 & 45.3 & 51 & $47.7 \%$ & 1.1 & 19.1 & $1,649.7$ & 9 & $8.4 \%$ & 1.4 & 10.0 & 397.5 & 47 & $43.9 \%$ \\
\hline 2004 & 88 & 1.0 & 6.9 & 24.8 & 57 & $64.8 \%$ & 11.2 & 400.0 & $5,068.8$ & 5 & $5.7 \%$ & 0.8 & 4.0 & 538.2 & 26 & $29.5 \%$ \\
\hline
\end{tabular}


Table 5

Transition Matrix for Revenue Growth Decile in Year $t$ and Year $t+1$ for Sample One Selected SIC Industries and All Other Companies: 1980 - 2004 (Portfolio 1 is lowest revenue growth...Portfolio 10 is highest revenue growth)

Panel A - Selected SIC Industries

\begin{tabular}{|c|c|c|c|c|c|c|c|c|c|c|c|c|}
\hline & \multicolumn{12}{|c|}{ Revenue Growth in Year $t+1$} \\
\hline & & port1 & port2 & port3 & port4 & port5 & port6 & port7 & port8 & port9 & port10 & Total \\
\hline \multirow{12}{*}{ 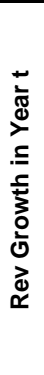 } & port 1 & $27.42 \%$ & $14.07 \%$ & $8.35 \%$ & $5.52 \%$ & $5.39 \%$ & $4.64 \%$ & $4.87 \%$ & $5.69 \%$ & $6.11 \%$ & $17.95 \%$ & $100.00 \%$ \\
\hline & port 2 & $13.68 \%$ & $19.40 \%$ & $15.91 \%$ & $10.16 \%$ & $7.96 \%$ & $7.96 \%$ & $7.73 \%$ & $6.74 \%$ & $5.56 \%$ & $4.93 \%$ & $100.00 \%$ \\
\hline & port 3 & $8.31 \%$ & $12.68 \%$ & $17.02 \%$ & $16.73 \%$ & $12.36 \%$ & $10.25 \%$ & $7.76 \%$ & $7.03 \%$ & $4.63 \%$ & $3.22 \%$ & $100.00 \%$ \\
\hline & port 4 & $5.29 \%$ & $8.05 \%$ & $13.02 \%$ & $21.96 \%$ & $19.07 \%$ & $12.16 \%$ & $8.28 \%$ & $5.62 \%$ & $4.08 \%$ & $2.47 \%$ & $100.00 \%$ \\
\hline & port 5 & $4.70 \%$ & $7.36 \%$ & $9.73 \%$ & $13.71 \%$ & $19.99 \%$ & $16.80 \%$ & $12.26 \%$ & $7.50 \%$ & $5.33 \%$ & $2.63 \%$ & $100.00 \%$ \\
\hline & port 6 & $4.63 \%$ & $7.66 \%$ & $9.92 \%$ & $9.99 \%$ & $12.45 \%$ & $17.75 \%$ & $17.19 \%$ & $10.45 \%$ & $6.87 \%$ & $3.09 \%$ & $100.00 \%$ \\
\hline & port 7 & $5.75 \%$ & $7.76 \%$ & $7.96 \%$ & $8.05 \%$ & $9.14 \%$ & $12.85 \%$ & $16.40 \%$ & $16.40 \%$ & $10.68 \%$ & $5.00 \%$ & $100.00 \%$ \\
\hline & port 8 & $6.87 \%$ & $7.92 \%$ & $7.56 \%$ & $6.61 \%$ & $6.18 \%$ & $8.54 \%$ & $12.42 \%$ & $18.63 \%$ & $18.17 \%$ & $7.10 \%$ & $100.00 \%$ \\
\hline & port 9 & $8.97 \%$ & $7.33 \%$ & $6.18 \%$ & $4.31 \%$ & $4.93 \%$ & $6.31 \%$ & $8.45 \%$ & $14.00 \%$ & $23.77 \%$ & $15.75 \%$ & $100.00 \%$ \\
\hline & port 10 & $14.37 \%$ & $7.76 \%$ & $4.37 \%$ & $2.96 \%$ & $2.53 \%$ & $2.76 \%$ & $4.64 \%$ & $7.96 \%$ & $14.79 \%$ & $37.87 \%$ & $100.00 \%$ \\
\hline & Total & $100.00 \%$ & $100.00 \%$ & $100.00 \%$ & $100.00 \%$ & $100.00 \%$ & $100.00 \%$ & $100.00 \%$ & $100.00 \%$ & $100.00 \%$ & $100.00 \%$ & \\
\hline & Missing & $8.64 \%$ & $4.10 \%$ & $3.40 \%$ & $3.31 \%$ & $3.76 \%$ & $5.39 \%$ & $7.37 \%$ & $11.04 \%$ & $17.04 \%$ & $35.95 \%$ & $100.00 \%$ \\
\hline
\end{tabular}

Panel B - All Other Companies

\begin{tabular}{|c|c|c|c|c|c|c|c|c|c|c|c|c|}
\hline & \multicolumn{12}{|c|}{ Revenue Growth in Year $t+1$} \\
\hline & & port1 & port2 & port3 & port4 & port5 & port6 & port7 & port8 & port9 & port10 & Total \\
\hline \multirow{12}{*}{ 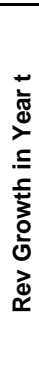 } & port 1 & $29.60 \%$ & $13.37 \%$ & $7.84 \%$ & $5.26 \%$ & $5.00 \%$ & $4.60 \%$ & $4.92 \%$ & $5.70 \%$ & $7.60 \%$ & $16.10 \%$ & $100.00 \%$ \\
\hline & port 2 & $14.55 \%$ & $19.06 \%$ & $14.94 \%$ & $10.78 \%$ & $8.48 \%$ & $7.28 \%$ & $6.80 \%$ & $6.37 \%$ & $6.01 \%$ & $5.72 \%$ & $100.00 \%$ \\
\hline & port 3 & $7.96 \%$ & $13.95 \%$ & $17.38 \%$ & $16.26 \%$ & $12.12 \%$ & $9.92 \%$ & $7.96 \%$ & $6.01 \%$ & $4.95 \%$ & $3.49 \%$ & $100.00 \%$ \\
\hline & port 4 & $5.82 \%$ & $10.23 \%$ & $13.91 \%$ & $17.52 \%$ & $16.12 \%$ & $12.26 \%$ & $9.37 \%$ & $6.64 \%$ & $4.91 \%$ & $3.22 \%$ & $100.00 \%$ \\
\hline & port 5 & $4.76 \%$ & $8.37 \%$ & $11.58 \%$ & $15.02 \%$ & $16.20 \%$ & $14.93 \%$ & $11.57 \%$ & $8.37 \%$ & $5.97 \%$ & $3.21 \%$ & $100.00 \%$ \\
\hline & port 6 & $4.68 \%$ & $7.55 \%$ & $9.62 \%$ & $10.52 \%$ & $13.97 \%$ & $16.19 \%$ & $15.19 \%$ & $10.96 \%$ & $7.23 \%$ & $4.09 \%$ & $100.00 \%$ \\
\hline & port 7 & $4.78 \%$ & $6.96 \%$ & $8.24 \%$ & $8.71 \%$ & $10.85 \%$ & $13.58 \%$ & $15.77 \%$ & $15.44 \%$ & $10.41 \%$ & $5.26 \%$ & $100.00 \%$ \\
\hline & port 8 & $5.47 \%$ & $7.05 \%$ & $6.38 \%$ & $6.86 \%$ & $7.96 \%$ & $10.27 \%$ & $13.96 \%$ & $18.02 \%$ & $16.02 \%$ & $8.03 \%$ & $100.00 \%$ \\
\hline & port 9 & $8.39 \%$ & $7.31 \%$ & $5.64 \%$ & $5.60 \%$ & $5.84 \%$ & $6.92 \%$ & $9.17 \%$ & $14.39 \%$ & $20.77 \%$ & $15.97 \%$ & $100.00 \%$ \\
\hline & port 10 & $13.99 \%$ & $6.14 \%$ & $4.46 \%$ & $3.46 \%$ & $3.47 \%$ & $4.05 \%$ & $5.29 \%$ & $8.09 \%$ & $16.13 \%$ & $34.93 \%$ & $100.00 \%$ \\
\hline & Total & $100.00 \%$ & $100.00 \%$ & $100.00 \%$ & $100.00 \%$ & $100.00 \%$ & $100.00 \%$ & $100.00 \%$ & $100.00 \%$ & $100.00 \%$ & $100.00 \%$ & \\
\hline & Missing & $8.36 \%$ & $5.35 \%$ & $6.02 \%$ & $5.45 \%$ & $5.55 \%$ & $6.28 \%$ & $7.58 \%$ & $10.08 \%$ & $14.23 \%$ & $31.09 \%$ & $100.00 \%$ \\
\hline
\end{tabular}

Panel C - Sample Two (Internet Companies)

\begin{tabular}{|c|c|c|c|c|c|c|c|c|c|c|c|c|}
\hline & \multicolumn{12}{|c|}{ Revenue Growth in Year $t+1$} \\
\hline & & port1 & port2 & port3 & port4 & port5 & port6 & port7 & port8 & port9 & port10 & Total \\
\hline \multirow{12}{*}{ 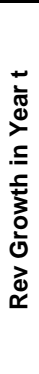 } & port 1 & $26.67 \%$ & $20.00 \%$ & $13.94 \%$ & $7.27 \%$ & $9.09 \%$ & $6.06 \%$ & $4.24 \%$ & $2.42 \%$ & $4.24 \%$ & $6.06 \%$ & $100.00 \%$ \\
\hline & port 2 & $11.45 \%$ & $19.88 \%$ & $21.69 \%$ & $15.06 \%$ & $15.06 \%$ & $9.64 \%$ & $4.22 \%$ & $1.20 \%$ & $1.20 \%$ & $0.60 \%$ & $100.00 \%$ \\
\hline & port 3 & $4.82 \%$ & $10.84 \%$ & $20.48 \%$ & $28.31 \%$ & $18.07 \%$ & $11.45 \%$ & $3.01 \%$ & $1.20 \%$ & $1.20 \%$ & $0.60 \%$ & $100.00 \%$ \\
\hline & port 4 & $6.06 \%$ & $7.27 \%$ & $10.91 \%$ & $18.79 \%$ & $18.18 \%$ & $16.36 \%$ & $13.94 \%$ & $3.64 \%$ & $1.82 \%$ & $3.03 \%$ & $100.00 \%$ \\
\hline & port 5 & $7.83 \%$ & $6.63 \%$ & $6.02 \%$ & $9.04 \%$ & $16.27 \%$ & $17.47 \%$ & $19.88 \%$ & $7.83 \%$ & $6.02 \%$ & $3.01 \%$ & $100.00 \%$ \\
\hline & port 6 & $7.23 \%$ & $10.24 \%$ & $6.02 \%$ & $7.83 \%$ & $8.43 \%$ & $13.25 \%$ & $21.69 \%$ & $12.65 \%$ & $7.23 \%$ & $5.42 \%$ & $100.00 \%$ \\
\hline & port 7 & $13.33 \%$ & $9.70 \%$ & $8.48 \%$ & $4.85 \%$ & $4.85 \%$ & $6.67 \%$ & $10.91 \%$ & $19.39 \%$ & $16.97 \%$ & $4.85 \%$ & $100.00 \%$ \\
\hline & port 8 & $9.64 \%$ & $6.02 \%$ & $6.02 \%$ & $3.01 \%$ & $4.22 \%$ & $6.02 \%$ & $12.65 \%$ & $25.30 \%$ & $16.87 \%$ & $10.24 \%$ & $100.00 \%$ \\
\hline & port 9 & $7.23 \%$ & $7.23 \%$ & $4.82 \%$ & $4.22 \%$ & $3.01 \%$ & $7.23 \%$ & $5.42 \%$ & $15.66 \%$ & $21.08 \%$ & $24.10 \%$ & $100.00 \%$ \\
\hline & port 10 & $5.45 \%$ & $2.42 \%$ & $1.82 \%$ & $1.21 \%$ & $3.03 \%$ & $6.06 \%$ & $3.64 \%$ & $10.91 \%$ & $23.64 \%$ & $41.82 \%$ & $100.00 \%$ \\
\hline & Total & $100.00 \%$ & $100.00 \%$ & $100.00 \%$ & $100.00 \%$ & $100.00 \%$ & $100.00 \%$ & $100.00 \%$ & $100.00 \%$ & $100.00 \%$ & $100.00 \%$ & \\
\hline & Missing & $2.59 \%$ & $1.20 \%$ & $0.80 \%$ & $2.20 \%$ & $5.59 \%$ & $7.19 \%$ & $11.98 \%$ & $12.38 \%$ & $16.77 \%$ & $39.32 \%$ & $100.00 \%$ \\
\hline
\end{tabular}

Panel D - Sample Three (Venture-backed Companies)

\begin{tabular}{|c|c|c|c|c|c|c|c|c|c|c|c|c|}
\hline & \multicolumn{12}{|c|}{ Revenue Growth in Year $t+1$} \\
\hline & & port1 & port2 & port3 & port4 & port5 & port6 & port7 & port8 & port9 & port10 & Total \\
\hline \multirow{12}{*}{ 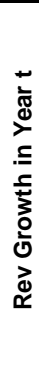 } & port 1 & $21.25 \%$ & $12.89 \%$ & $9.76 \%$ & $5.92 \%$ & $6.62 \%$ & $6.62 \%$ & $6.62 \%$ & $9.06 \%$ & $7.32 \%$ & $13.94 \%$ & $100.00 \%$ \\
\hline & port 2 & $13.89 \%$ & $24.65 \%$ & $20.49 \%$ & $12.85 \%$ & $7.99 \%$ & $4.86 \%$ & $5.21 \%$ & $3.82 \%$ & $2.78 \%$ & $3.47 \%$ & $100.00 \%$ \\
\hline & port 3 & $10.76 \%$ & $14.24 \%$ & $21.53 \%$ & $16.67 \%$ & $12.85 \%$ & $6.60 \%$ & $5.56 \%$ & $4.51 \%$ & $3.13 \%$ & $4.17 \%$ & $100.00 \%$ \\
\hline & port 4 & $10.42 \%$ & $15.97 \%$ & $13.19 \%$ & $19.44 \%$ & $17.01 \%$ & $10.42 \%$ & $6.25 \%$ & $2.78 \%$ & $3.47 \%$ & $1.04 \%$ & $100.00 \%$ \\
\hline & port 5 & $8.68 \%$ & $6.94 \%$ & $12.50 \%$ & $12.15 \%$ & $16.32 \%$ & $12.85 \%$ & $12.85 \%$ & $7.29 \%$ & $6.25 \%$ & $4.17 \%$ & $100.00 \%$ \\
\hline & port 6 & $9.38 \%$ & $9.72 \%$ & $5.56 \%$ & $12.15 \%$ & $12.85 \%$ & $16.32 \%$ & $14.58 \%$ & $10.07 \%$ & $5.90 \%$ & $3.47 \%$ & $100.00 \%$ \\
\hline & port 7 & $7.99 \%$ & $5.90 \%$ & $6.94 \%$ & $7.29 \%$ & $11.46 \%$ & $17.01 \%$ & $12.50 \%$ & $14.58 \%$ & $10.42 \%$ & $5.90 \%$ & $100.00 \%$ \\
\hline & port 8 & $6.55 \%$ & $4.14 \%$ & $2.41 \%$ & $4.48 \%$ & $6.90 \%$ & $14.48 \%$ & $15.17 \%$ & $20.69 \%$ & $13.45 \%$ & $11.72 \%$ & $100.00 \%$ \\
\hline & port 9 & $5.59 \%$ & $4.55 \%$ & $4.90 \%$ & $6.29 \%$ & $4.55 \%$ & $6.29 \%$ & $16.43 \%$ & $16.78 \%$ & $19.23 \%$ & $15.38 \%$ & $100.00 \%$ \\
\hline & port 10 & $5.23 \%$ & $1.05 \%$ & $2.79 \%$ & $2.79 \%$ & $3.48 \%$ & $4.53 \%$ & $4.88 \%$ & $10.45 \%$ & $28.22 \%$ & $36.59 \%$ & $100.00 \%$ \\
\hline & Total & $100.00 \%$ & $100.00 \%$ & $100.00 \%$ & $100.00 \%$ & $100.00 \%$ & $100.00 \%$ & $100.00 \%$ & $100.00 \%$ & $100.00 \%$ & $100.00 \%$ & \\
\hline & Missing & $10.51 \%$ & $7.10 \%$ & $5.97 \%$ & $5.38 \%$ & $6.22 \%$ & $6.96 \%$ & $6.86 \%$ & $7.20 \%$ & $12.78 \%$ & $31.03 \%$ & $100.00 \%$ \\
\hline
\end{tabular}


Table 6

Correlation For 10 Portfolios Ranked on MKT $/ R$ REV $_{t}$ Between (A) Median MKT/REV and Median Annual Revenue Growth, and (B) Annual Revenue Growth Across Time Periods

Panel A: Correlation Between Median MKT/REV and Median Annual Revenue Growth for 10 Portfolios

\begin{tabular}{|c|c|c|c|c|}
\hline & \multicolumn{2}{|c|}{ Sample One } & \multirow{2}{*}{$\begin{array}{c}\text { Sample Two } \\
\text { Internet } \\
\text { Companies } \\
\end{array}$} & \multirow{2}{*}{$\begin{array}{c}\text { Sample Three } \\
\text { VC Backed } \\
\text { Companies } \\
\end{array}$} \\
\hline & $\begin{array}{c}\text { Selected SIC } \\
\text { Industries }\end{array}$ & $\begin{array}{c}\text { All Other } \\
\text { Companies }\end{array}$ & & \\
\hline \multicolumn{5}{|c|}{ Positive Revenue Growth Portfolios } \\
\hline \multicolumn{5}{|c|}{$\mathrm{MKT}_{\mathrm{t}} / \mathrm{REV}_{\mathrm{t}} \&$ REV Growth $\mathrm{t}_{\mathrm{t} / \mathrm{t}}$} \\
\hline Pearson & 0.97 & 0.99 & 0.95 & 0.83 \\
\hline Spearman & 1.00 & 0.98 & 0.60 & 0.92 \\
\hline \multicolumn{5}{|c|}{$\mathrm{MKT}_{\mathrm{t}} / \mathrm{REV}_{\mathrm{t}} \& \mathrm{REV}$ Growth $_{\mathrm{t}+1 / \mathrm{t}}$} \\
\hline Pearson & 0.93 & 0.97 & 0.98 & 1.00 \\
\hline Spearman & 1.00 & 1.00 & 0.96 & 1.00 \\
\hline \multicolumn{5}{|c|}{$\mathrm{MKT}_{\mathrm{t}} / \mathrm{REV}_{\mathrm{t}} \&$ REV Growth $\mathrm{t}_{\mathrm{t}+2 / \mathrm{t}+1}$} \\
\hline Pearson & 0.86 & 0.92 & -0.04 & 0.99 \\
\hline Spearman & 1.00 & 1.00 & 0.17 & 0.98 \\
\hline \multicolumn{5}{|c|}{ Negative Revenue Growth Portfolios } \\
\hline \multicolumn{5}{|c|}{$\mathrm{MKT}_{\mathrm{t}} / \mathrm{REV}_{\mathrm{t}} \& \mathrm{REV}$ Growth $_{\mathrm{t} / \mathrm{t}-1}$} \\
\hline Pearson & -0.98 & -0.99 & -0.93 & -0.92 \\
\hline Spearman & -0.80 & -0.51 & 0.01 & -0.83 \\
\hline \multicolumn{5}{|c|}{$\mathrm{MKT}_{\mathrm{t}} / \mathrm{REV}_{\mathrm{t}} \&$ REV Growth $\mathrm{t}_{\mathrm{t}+\mathrm{t}}$} \\
\hline Pearson & 0.97 & 0.89 & 0.87 & 0.79 \\
\hline Spearman & 1.00 & 0.99 & 0.78 & 0.90 \\
\hline \multicolumn{5}{|c|}{$\mathrm{MKT}_{\mathrm{t}} / \mathrm{REV}_{\mathrm{t}} \& \mathrm{REV}$ Growth $_{\mathrm{t}+2 / \mathrm{t}+1}$} \\
\hline Pearson & 0.91 & 0.72 & 0.59 & 0.70 \\
\hline Spearman & 0.99 & 0.96 & 0.45 & 0.89 \\
\hline
\end{tabular}

Panel B: Correlation Between Median Annual Revenue Growth of Portfolios Across Time Periods

\begin{tabular}{|c|c|c|c|c|}
\hline & \multicolumn{2}{|c|}{ Sample One } & \multirow{2}{*}{$\begin{array}{c}\text { Sample Two } \\
\text { Internet } \\
\text { Companies }\end{array}$} & \multirow{2}{*}{$\begin{array}{c}\text { Sample Three } \\
\text { VC Backed } \\
\text { Companies }\end{array}$} \\
\hline & $\begin{array}{c}\text { Selected SIC } \\
\text { Industries }\end{array}$ & $\begin{array}{c}\text { All Other } \\
\text { Companies }\end{array}$ & & \\
\hline \multicolumn{5}{|c|}{ Positive Revenue Growth Portfolios } \\
\hline \multicolumn{5}{|c|}{ Year $\mathrm{t} \&$ Year $\mathrm{t}+1$} \\
\hline Pearson & 0.99 & 0.95 & 0.91 & 0.83 \\
\hline Spearman & 1.00 & 0.99 & 0.71 & 0.92 \\
\hline \multicolumn{5}{|c|}{ Year $\mathrm{t} \&$ Year $\mathrm{t}+2$} \\
\hline Pearson & 0.94 & 0.89 & -0.03 & 0.86 \\
\hline Spearman & 0.99 & 0.99 & 0.17 & 0.96 \\
\hline \multicolumn{5}{|c|}{ Year $\mathrm{t}+1 \&$ Year $\mathrm{t}+2$} \\
\hline Pearson & 0.98 & 0.98 & 0.06 & 0.99 \\
\hline Spearman & 1.00 & 1.00 & 0.31 & 0.98 \\
\hline \multicolumn{5}{|c|}{ Negative Revenue Growth Portfolios } \\
\hline \multicolumn{5}{|c|}{ Year $\mathrm{t} \&$ Year $\mathrm{t}+1$} \\
\hline Pearson & -0.98 & -0.82 & -0.76 & -0.90 \\
\hline Spearman & -0.80 & -0.46 & -0.01 & -0.89 \\
\hline \multicolumn{5}{|c|}{ Year $\mathrm{t} \&$ Year $\mathrm{t}+2$} \\
\hline Pearson & -0.95 & -0.62 & -0.63 & -0.84 \\
\hline Spearman & -0.78 & -0.34 & -0.42 & -0.74 \\
\hline \multicolumn{5}{|c|}{ Year $t+1 \&$ Year $t+2$} \\
\hline Pearson & 0.98 & 0.95 & 0.45 & 0.90 \\
\hline Spearman & 0.99 & 0.98 & 0.37 & 0.80 \\
\hline
\end{tabular}


Table 7

\section{Regression Analysis (Rank Regression) Using (a) MKT $/ \mathbf{R E V}_{\mathrm{t}}$ As Dependent Variable, and (b) Revenue Growth, Company Size, Profitability and Other Variables}

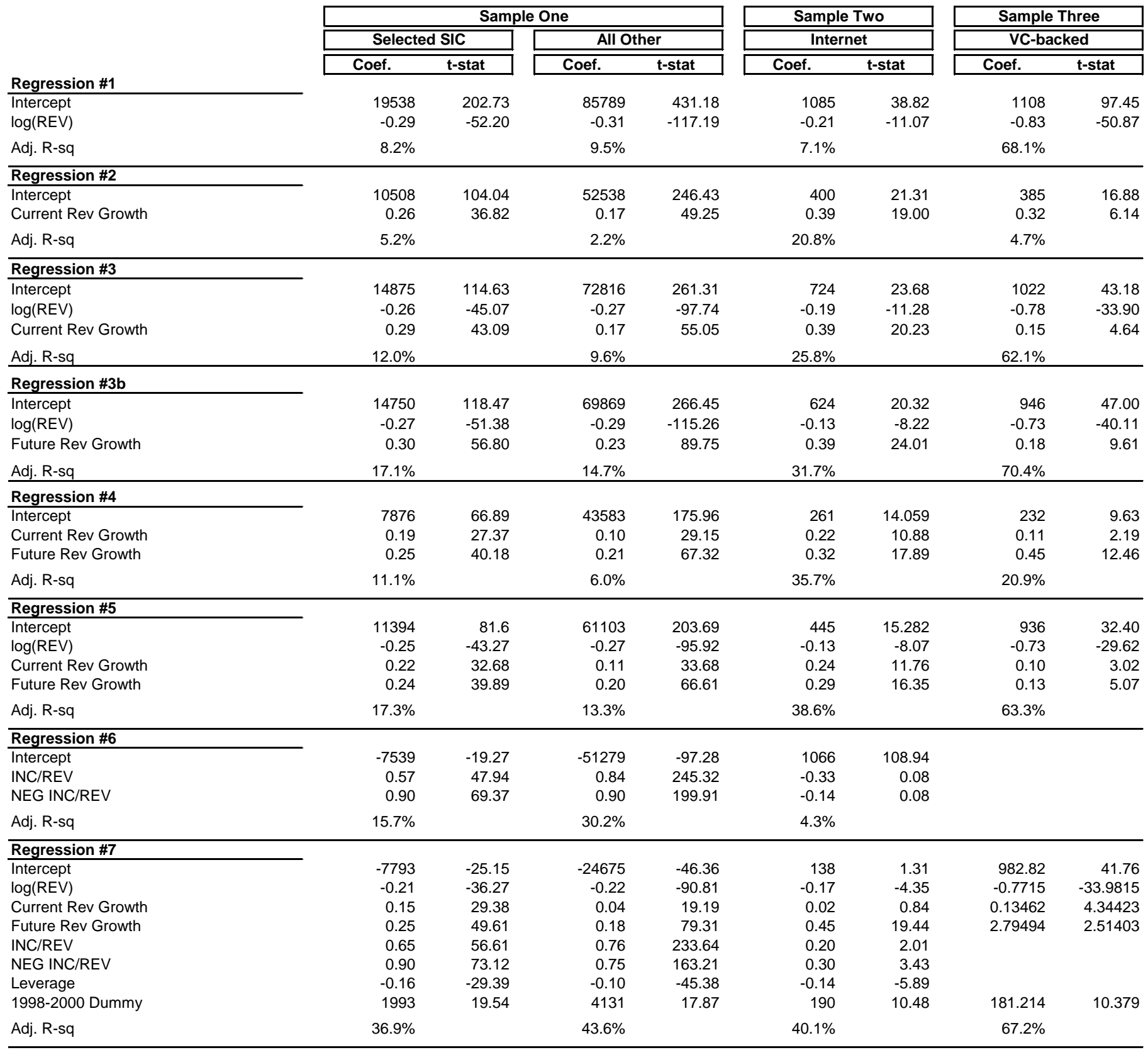




\section{Table 8}

Sample One Regression Analysis (Rank Regression) Using $\mathbf{M K T}_{\mathrm{t}} / \mathbf{R E V}_{\mathrm{t}}$ as Dependent Variables For Three Subsamples Based on Sign of Current Revenue Growth (Panel A: Positive; Panel B: Negative; Panel C: Missing Observations)

\begin{tabular}{|c|c|c|c|c|}
\hline \multicolumn{5}{|c|}{ Positive Current Revenue Growth } \\
\hline & \multicolumn{2}{|c|}{ Selected SIC } & \multicolumn{2}{|c|}{ All Other } \\
\hline & Coef. & t-stat & Coef. & t-stat \\
\hline Intercept & -5830.62 & -29.74 & -20794.45 & -54.55 \\
\hline $\log (\mathrm{REV})$ & -0.06 & -8.43 & -0.13 & -46.55 \\
\hline Current Rev Growth & 0.22 & 33.17 & 0.10 & 34.98 \\
\hline Future Rev Growth & 0.18 & 27.40 & 0.14 & 49.79 \\
\hline INC/REV & 0.66 & 58.83 & 0.77 & 225.51 \\
\hline NEG INC/REV & 0.89 & 65.96 & 0.76 & 135.24 \\
\hline Leverage & -0.15 & -22.73 & -0.08 & -29.73 \\
\hline 1998-2000 Period & 1075.88 & 14.10 & 1937.86 & 11.55 \\
\hline R-sq & $41.68 \%$ & & $49.37 \%$ & \\
\hline nobs & 15,131 & & 73,574 & \\
\hline
\end{tabular}

\begin{tabular}{|c|c|c|c|c|}
\hline \multicolumn{5}{|c|}{ Negative Current Revenue Growth } \\
\hline & \multicolumn{2}{|c|}{ Selected SIC } & \multicolumn{2}{|c|}{ All Other } \\
\hline & Coef. & t-stat & Coef. & t-stat \\
\hline Intercept & 1198.46 & 5.32 & -1170.76 & -3.65 \\
\hline $\log (\mathrm{REV})$ & -0.28 & -17.90 & -0.30 & -54.19 \\
\hline Current Rev Growth & -0.09 & -6.82 & -0.11 & -19.60 \\
\hline Future Rev Growth & 0.20 & 18.35 & 0.16 & 33.26 \\
\hline INC/REV & 0.34 & 8.58 & 0.80 & 81.67 \\
\hline NEG INC/REV & 0.56 & 15.22 & 0.64 & 56.65 \\
\hline Leverage & -0.13 & -11.23 & -0.12 & -22.85 \\
\hline 1998-2000 Period & 252.60 & 4.53 & 695.91 & 5.52 \\
\hline R-sq & $26.62 \%$ & & $32.89 \%$ & \\
\hline nobs & 6,353 & & 27,929 & \\
\hline
\end{tabular}

\begin{tabular}{|c|c|c|c|c|}
\hline \multicolumn{5}{|c|}{ Missing Current Revenue Growth } \\
\hline & \multicolumn{2}{|c|}{ Selected SIC } & \multicolumn{2}{|c|}{ All Other } \\
\hline & Coef. & t-stat & Coef. & t-stat \\
\hline Intercept & -7.75 & -0.07 & -1007.32 & -5.39 \\
\hline $\log (R E V)$ & -0.26 & -20.02 & -0.36 & -55.49 \\
\hline Current Rev Growth & & & & \\
\hline Future Rev Growth & 0.25 & 23.62 & 0.24 & 42.57 \\
\hline INC/REV & 0.39 & 15.26 & 0.57 & 66.29 \\
\hline NEG INC/REV & 0.79 & 28.56 & 0.78 & 64.24 \\
\hline Leverage & -0.20 & -18.66 & -0.11 & -19.51 \\
\hline 1998-2000 Period & 277.61 & 8.08 & 1145.19 & 12.80 \\
\hline R-sq & $56.56 \%$ & & $53.69 \%$ & \\
\hline nobs & 4064 & & 15681 & \\
\hline
\end{tabular}




\section{REFERENCES}

Allee, K.D., \& Yohn, T.L. 2009, 'The Demand for Financial Statements in an Unregulated Environment: An Examination of the Production and Use of Financial Statements by Privately Held Small Businesses', The Accounting Review, vol. 84, no. 1, pp. 1-25.

Altman, E.I. 2000, 'Predicting Financial Distress of Companies Revisiting the Z-Score and Zeta® Models', Working Paper, New York University.

Armstrong, C., Davila, A., \& Foster, G. 2006, 'Venture-Backed Private Equity Valuation and Financial Statement Information', Review of Accounting Studies, vol. 17, pp. 119-154.

Armstrong, C., Davila, A., Foster, G., \& Hand, J.R.M. 2006, 'Biases in Multi-Year Management Financial Forecasts: Evidence from Private Venture-Backed U.S. Companies,' Review of Accounting Studies, vol. 12, no. 2-3, pp. 183-215.

Ball, R. \& Foster, G. 1982, 'Corporate Financial Reporting: a Methodological Review of Empirical Research', Journal of Accounting Research, vol. 20, pp. 161-234.

Ball, R. \& Watts, R. 1972, 'Some Time Series Properties of Accounting Income.' The Journal of Finance, vol. 27, no. 3, pp. 663-681.

Bartov, E., Mohanram, P. \& Seethamraju, C. 2002, 'Valuation of Internet stocks-An IPO perspective', Journal of Accounting Research, vol. 40, no. 2, pp. 321-346.

Bauman, C.C., Bauman, M.P. \& Das, S. 2010, 'Valuation Consequences of Regulatory Changes in Revenue Recognition: Evidence from Advertising Barter Sales', Advances in Accounting, vol. 26, no. 2, pp. 177-184.

Beaver, W.H. 1989, Financial Reporting: An Accounting Revolution, Prentice-Hall, Englewood Cliffs, N.J., $2^{\text {nd }}$ edition.

Beaver, W.H. \& Morse, D. 1978, 'What Determines Price-Earnings Ratios?' Financial Analysts Journal, vol. 34, no. 4, pp. 65-79.

Berger, P.G. 2003, 'Discussion of Differential Market Reactions to Revenue and Expense Surprises,' Review of Accounting Studies, vol. 8, pp. 213-220.

Black, F. \& Scholes, M. 1973, 'The Pricing of Options and Corporate Liabilities', Journal of Political Economy, vol. 81, no. 3, pp. 637-654.

Bowen, R.M., Davis, A.K., \& Rajgopal, S. 2002, 'Determinants of Revenue Reporting Practices for Internet Firms', Contemporary Accounting Research, vol. 19, pp. 523-562.

Callen, J.L., Robb, S.W.G., \& Segal, D. 2004, 'Revenue Manipulation and Restatements by Loss Firms', Working Paper, University of Toronto.

Cassar, G. 2009, 'Financial Statement and Projection Preparation in Start-Up Ventures', The Accounting Review, vol. 84, no. 1, pp. 27-51. 
Collins, D.M.; M. Pincus; and H. Xie. 'Equity Valuation and Negative Earnings: The Role of Book Value of Equity.' The Accounting Review 74 (1999): 29-62.

Core, J.E.; W.R. Guay; and A.Van Buskirk. 'Market Valuations in the New Economy,' Journal of Accounting \& Economics 34 (2003): 43-67.

Davila, A. 2005, 'An Exploratory Study on the Emergence of Management Control Systems: Formalizing Human Resources in Small Growing Firms', Accounting, Organizations and Society, vol. 30 , no. 3 , pp. 223-248.

Davila, A., \& Foster, G. 2005, 'Management Accounting Systems Adoption Decisions: Evidence and Performance Implications from Startup Companies', The Accounting Review, vol. 80, pp. 1039-1068.

Davila, A. \& Foster, G. 2007, 'Management Control Systems in Early-Stage Startup Companies', The Accounting Review, vol. 82, no. 4, pp. 907-937.

Davila, A., Foster, G., \& Gupta, M. 2003, 'Venture Capital Financing and the Growth of Startup Companies', Journal of Business Venturing, vol. 18, pp. 689-708.

Davila, A., Foster, G., \& Jia, N. 2010, 'Building Sustainable High Growth Startup Companies: Management Systems As An Accelerator', California Management Review, vol. 52, no. 3, pp. 79105.

Davila, A., Foster, G., \& Li, M. 2009, 'Reasons for Management Control System Adoption: Insights from Product Development Choice by Early Stage Entrepreneurial Companies', Accounting Organizations and Society, vol. 34, nos. 3-4, pp. 322-247.

Davis, A. 2002, 'The value relevance of revenue for Internet firms: Does reporting grossed-up or barter revenue make a difference', Journal of Accounting Research, vol. 40, no. 2, pp. 445-484.

Demers, E. \& Lev, B. 2000, 'A Rude Awakening: Internet Shakeout in 2000', Review of Accounting Studies, vol. 6, pp. 331-359.

Demers, E. \& Lewellen, K. 2003, 'The marketing role of IPOs: Evidence from Internet stocks', Journal of Financial Economics, vol. 68, pp. 413-437.

Ertimur, Y., Livnat, J., \& Martikainen, M. 2003, 'Differential Market Responses to Revenue and Expense Surprises', Review of Accounting Studies, vol. 8, pp. 185-211.

Ertimur, Y., Mayew, W.J., \& Stubben, S.R. 2011, 'Analyst Reputation and the Issuance of Disaggregated Earnings Forecasts to I/B/E/S', Review of Accounting Studies, forthcoming.

Fama, E.F., \& Miller, M.H. 1972, The Theory of Finance, Holt, Rinehart and Winston, Inc., New York.

Fama, E. F., \& French, K.R. 2004, 'New Lists: Fundamentals and Survival Rates', Journal of Financial Economics, vol. 73, pp. 229-269.

Foster, G. 1986, Financial Statement Analysis, Prentice-Hall, $2^{\text {nd }}$ edition, Englewood Cliffs, N.J. 
Foster, G., Davila, A. Haemmig, M., He, X., Jia, N., von Bismarck, M., \& Wellman, K. 2011, Global Entrepreneurship and the Successful Growth Strategies of Early-Stage Companies, World Economic Forum USA Inc.

Ghosh, A., Gu, Z., \& Jain, P. 2005, 'Sustained Revenue and Earnings Growth, Earning Quality, and Earnings Response Coefficients', Review of Accounting Studies, vol. 10, pp. 33-57.

Hand, J.R.M. 2001, 'The Role of Book Income, Web Traffic, and Supply and Demand in the Pricing of U.S. Internet Stocks', European Finance Review, vol. 5, pp. 295-317.

Hand, J.R.M. 2003, 'Profits, Losses and the Nonlinear Pricing of Internet Stocks', Intangible Assets: Values, Measures and Risks, eds. J.R.M. Hand and B. Lev, Oxford University Press, New York.

Hand, J.R.M. 2005, 'The Value Relevance of Financial Statements in the Venture Capital Market', The Accounting Review, vol. 80, pp. 613-648.

Hand, J.R.M. 2011, 'What drives the top line? Determinants of Sales Revenue in Private VentureBacked Firms', Entrepreneurial Finance Handbook, ed. D. Cumming, Oxford University Press, New York.

Hayn, C. 1995, 'The Information Content of Losses', Journal of Accounting and Economics, vol. 20, pp. 125-153.

Joos, P. \& Plesko, G.A. 2005, 'Valuing Loss Firms', The Accounting Review, vol. 80, pp. 847-870.

Keating, E.K., Lys, T.Z., \& Magee, R.P. 2003, 'Internet Downturn: Finding Valuation Factors in Spring 2000', Journal of Accounting \& Economics, vol. 34, pp. 189-236.

Keung, E.C. 2010, 'Do Supplementary Sales Forecasts Increase the Credibility of Financial Analysts' earnings forecasts', The Accounting Review, vol. 86, no. 6, pp. 2047-2074.

Liu, J., Nissim, D. \& Thomas, J. 2002, 'Equity Valuation Using Multiples', Journal of Accounting Research, vol. 40, no. 1, pp. 135-172.

Ljungqvist, A., \& Wilhelm, W.J.2003, 'IPO Pricing in the Dot-Com Bubble', Journal of Finance, vol. 58, no. 2, pp. 723-752.

Loughran, T. \& Ritter, J. 2004, 'Why Has IPO Underpricing Changed Over Time?' Financial Management, vol. 33, no. 3, pp. 5-37.

Miller, M.H. \& Modigliani, F. 1961, 'Dividend Policy, Growth and the Valuation of Shares", Journal of Business, vol. 34, no. 4, pp. 411-433.

Ofek, E. \& Richardson, M. 2002, 'The Valuation and Market Rationality of Internet Stock Prices', Oxford Review of Economic Policy, vol. 18, pp. 265-287.

Ofek, E. \& Richardson, M. 2003, 'DotCom Mania: The Rise and Fall of Internet Stock Prices', Journal of Finance, vol. 58, no. 3, pp. 1113-1138.

O’Hara, S. \& Lowry, V. 2009, 'Paying Attention to Sales: How Market-Cap-To-Revenue Makes a Difference', MarketWatch. 
Palepu, K.G. \& Healy, P.M. 2007, Business Analysis and Valuation Using Financial Statements, Text and Cases, South-Western, Ohio.

Penman, S. 2009, Financial Statement Analysis and Security Valuation, McGraw-Hill/Irwin, $4^{\text {th }}$ edition, New York.

Rajgopal, S., Venkatachalam, M., \& Kotha, S. 2002, 'Managerial actions, stock returns, and earnings: The case of business-to-business Internet firms', Journal of Accounting Research, vol. 40, no. 2, pp. 529-556.

Sandino, T. 2007, 'Introducing the First Management Control Systems: Evidence from the Retail Sector', The Accounting Review, vol. 82, no. 1, pp. 265-293.

Schultz, P., \& Zaman, M. 2001, 'Do the Individuals Closest to Internet Firms Believe They Are Overvalued?' Journal of Financial Economics, vol. 59, pp. 347-381.

Stubben, S.R. 2010, 'Discretionary Revenues as a Measurement of Earnings Mangement', The Acounting Review, vol. 85, no. 2, pp. 695-717.

Trueman, B., Wong, M.H.F., \& Zhang, X-J. 2000, 'The eyeballs have it: Searching for the value in Internet stocks', Journal of Accounting Research, vol. 38, pp. 137-162.

Trueman, B., Wong, M.H.F., \& Zhang, X.J. 2001, 'Back to basics: Forecasting the revenues of Internet firms', Review of Accounting Studies, vol. 6, pp. 305-329.

Trueman, B., Wong, M.H.F., \& Zhang, X.J. 2003, 'Anomalous stock returns around Internet firms' earnings announcements', Journal of Accounting \& Economics, vol. 34, pp. 249-271. 